\title{
Variability in pigment composition and optical characteristics of phytoplankton in the Labrador Sea and the Central North Atlantic
}

\author{
Vivian A. Lutz ${ }^{1,3, *}$, Shubha Sathyendranath ${ }^{1,2}$, Erica J. H. Head ${ }^{2}$, William K. W. Li ${ }^{2}$ \\ ${ }^{1}$ Department of Oceanography, Dalhousie University, Halifax, Nova Scotia B3H 4J1, Canada \\ ${ }^{2}$ Bedford Institute of Oceanography, Box 1006, Dartmouth, Nova Scotia B2Y 4A2, Canada \\ ${ }^{3}$ Present address: INIDEP, Paseo Victoria Ocampo No. 1, 7600 Mar del Plata, Argentina
}

\begin{abstract}
The relationships between photoadaptation, photoacclimation, cell size and the optical characteristics of the phytoplankton community were studied in 2 areas of the Atlantic Ocean. Pigment composition, absorption and fluorescence excitation spectra were analyzed for samples collected during 2 spring cruises: one in the Labrador Sea and the other in the Central North Atlantic. Photoadaptation (i.e. evolutionary adaptation of different species leading to acquisition of different pigment composition) was evident in the distribution of the main phytoplankton pigments in the area. Photoacclimation (i.e. temporary changes in pigment concentrations in a given species) was also noticeable in the changes in pigment composition and optical characteristics of phytoplankton with changes in depth. Size fractionation of samples from the depth of the chlorophyll a (chl a) maximum showed that, on average, chl a concentration and the values of absorption and fluorescence were dominated by the $>2 \mu \mathrm{m}$ fraction of phytoplankton. Spectral variations in absorption and fluorescence excitation were, however, similar for the small and for the large size fractions. A distinct regional distribution of algal groups was observed, in which prokaryotic picophytoplankton (size class $<2 \mu \mathrm{m}$ ) dominated in oligotrophic subtropical regions and larger cells (size class $>2 \mu \mathrm{m}$ ) dominated in coastal areas and at higher latitudes. Some significant relationships were observed between the relative abundances of pigments characteristic of certain algal groups and optical properties of the sample. For example, the ratio of absorption at $440 \mathrm{~nm}$ to that at $676 \mathrm{~nm}$ was positively correlated with the ratio of zeaxanthin to chl $a$, indicating high abundance of picophytoplankton, especially the cyanobacteria Synechococcus and Prochlorococcus. The ratio of absorption at $555 \mathrm{~nm}$ to that at $623 \mathrm{~nm}$ was positively correlated with the abundance of phycoerythrin-containing Synechococcus. These results show that useful information about phytoplankton group composition and photoacclimation state can be retrieved from optical properties at a regional scale.
\end{abstract}

KEY WORDS: Phytoplankton pigments - Absorption - Fluorescence excitation - Photoadaptation · Photoacclimation $\cdot$ Size fractionation

\section{INTRODUCTION}

The wide diversity observed in phytoplankton communities in the ocean is the result of speciesdependent differences in growth under different environmental conditions, such as nutrient availability, light field, stability of the water column and grazing pressure (see Margalef 1978, Kiørboe 1993). Among these factors, the effect of light quality and quantity on phytoplankton growth has received special attention since light is the driving force for photosynthesis and there are strong light gradients in the ocean. Phytoplankton possess taxon-specific suites of pigments arranged in pigment-protein complexes in their photosynthetic (PS) apparatuses (e.g. Porra et al. 1997). Each one of these pigment-complexes absorbs in a particu- 
lar region of the light spectrum. Thus, according to its pigment composition, each phytoplankton species should have a characteristic absorption spectrum (Prézelin 1981, Larkum \& Barret 1983, Boczar \& Prézelin 1989, Johnsen et al. 1994, 1997, Porra et al. 1997), which may be subject to some modification according to environmental conditions. Chromatic adaptation, that is, adaptation of a given species to particular spectral light conditions, has been reported to occur in the ocean (Glover et al. 1986, Takahashi et al. 1989, Bidigare et al. 1990a). Algae are also able to change the amount of pigment per cell according to the intensity of irradiance to which they are exposed (reviewed in Richardson et al. 1983, Falkowski \& La Roche 1991). In the pelagic environment, the magnitude and spectral quality of light change simultaneously, making it difficult to separate chromatic from intensity adaptation. In this paper, we make a distinction between the terms photoadaptation and photoacclimation following Falkowski \& La Roche (1991). The term photoadaptation will be used to refer to the evolutionary, genetic, adaptation of different species, leading to development of particular suites of pigments in response to the light regimes in which they grow; hence, it involves adaptation to both light quality and intensity. The term photoacclimation, on the other hand, will be used to refer to the temporary changes in the pigment composition of a given species in response to changes in light intensity. Photoacclimation could also refer to fast (order of minutes) changes in the organization of the PS apparatus, for example state transitions (e.g. Bonaventura \& Myers 1969) and the xanthophyll cycle (e.g. Demers et al. 1991), but processes on such short time scales are beyond the scope of this study.

Another factor affecting the absorption of phytoplankton, besides the pigment composition, is the packaging effect, that is, the reduction in absorption efficiency of a substance enclosed in a particle in comparison with the absorption efficiency of the same substance in solution (Duysens 1956). In phytoplankton, the packaging effect is a function of the diameter of the cell and the intracellular concentration of pigments (Duysens 1956, Morel \& Bricaud 1981, Sathyendranath et al. 1987). It is now well known that the phytoplankton community in the subtropical open ocean is dominated by small cells (Johnson \& Sieburth 1979, Platt \& Li 1986, Chisholm et al. 1988). It has also been suggested that such a community of small-size phytoplankton forms a background biomass superimposed by larger cells in coastal and nutrient-rich waters in the ocean (Malone 1980, Yentsch \& Spinrad 1987, Yentsch 1990, Chisholm 1992).

The optical characteristics of phytoplankton depend on both the species composition, including size compo- sition, and the photoacclimation status of the cells. Hence, studies on pigment composition and optical characteristics of phytoplankton provide insight as to why different groups of phytoplankton are distributed the way they are and on their ability to adjust to a variable light environment. Information on the characteristics of phytoplankton absorption is a necessary input for primary production models (e.g. Morel 1978, Sathyendranath \& Platt 1989, Kyewalyanga et al. 1997). Algorithms used to retrieve phytoplankton biomass by remote sensing are based on the relationship between ocean color, which is strongly influenced by phytoplankton absorption, and chl a concentration (Gordon \& Morel 1983, Sathyendranath \& Platt 1989, IOCCG 1998). Thus, knowledge of the optical characteristics of different groups of algae and their photoacclimation status in the ocean are useful for interpretation of ocean-color data.

The main objective of this work was to investigate the influences of photoadaptation, photoacclimation and cell size on the optical properties of phytoplankton communities. Therefore, absorption and fluorescence characteristics of phytoplankton and their pigment composition were surveyed in 2 contrasting environments of the North Atlantic: the Central North Atlantic and the Labrador Sea. The effect of cell size in determining variations in the optical properties of phytoplankton was studied by analyzing 2 size fractions, large $(>2 \mu \mathrm{m})$ and small $(<2 \mu \mathrm{m})$.

\section{MATERIALS AND METHODS}

Sampling. Details on the sampling procedure have been previously described (Lutz et al. 1998). An extensive area of the North Atlantic was covered during 2 cruises in spring 1993 (Canarias cruise, from 18 May to 7 June; Fig. 1) and spring 1994 (Labrador cruise, from 25 May to 9 June; Fig. 1). At each station, seawater samples were collected at 7 depths for the determination of nitrate concentrations and samples were filtered onto GF/F filters at a pressure $<35 \mathrm{kPa}$, for the determination of extracted pigments, absorption and fluorescence excitation spectra. Seawater samples from 3 depths (surface, the depth of the chl a maximum (DCM) and one chosen depth below the DCM) were size fractionated. That is to say, in addition to the 'total' sample filtered through GF/F glass fiber filter, another sample was first filtered through a $2 \mu \mathrm{m}$ Nuclepore filter and the filtrate was then filtered through a GF/F filter to represent the 'small' $(<2 \mu \mathrm{m})$ fraction. Samples of 250 to $500 \mathrm{ml}$ of seawater from these 3 selected depths were filtered through $0.6 \mu \mathrm{m}$ Nuclepore filters for the determination of fluorescence emission by phycoerythrin. 
Pigment determination. Samples (GF/F filters) for pigment determination were preserved in liquid nitrogen until analysis, which was within a few months of each cruise. Concentrations of solvent-soluble pigments were measured by HPLC following the technique described by Head \& Horne (1993). It should be noted that this method uses $90 \%$ acetone as a solvent for extraction of the pigments, which might cause some underestimation in the concentrations of pigments of some species such as Synechococcus (Jeffrey \& Vesk 1997). The relative abundance of water-soluble phycoerythrin was determined on board following the method of Wyman (1992). Cells retained on a $0.6 \mu \mathrm{m}$ Nuclepore filter were resuspended in $50 \%$ glycerol and after approximately 5 min the fluorescence emission at $570 \mathrm{~nm}$ (excitation light fixed at $520 \mathrm{~nm}$ ) was measured on a SPEX-Fluorolog F111A spectrofluorometer.

Fluorescence excitation spectra. Fluorescence excitation spectra were measured on particulate samples retained on GF/F glass fiber filters, rather than in suspension as normally done (e.g. Sosik \& Mitchell 1995, Johnsen et al. 1997), to enable detection of signals from the extremely low concentrations of phytoplankton found in oligotrophic areas. Fluorescence was measured without the addition of DCMU (3-[3,4-dichlorophenyl] 1-1 dimethylurea). Hence, some variations in the shape of the fluorescence excitation spectra could be expected due to variable fluorescence caused by differences in the capacity of the lamp to close the reaction centers at different wavelengths, as suggested by Johnsen \& Sakshaug (1993). Measurements were made on board immediately after filtering the samples. Spectra were corrected for variability in the response of the excitation lamp according to the method proposed by Culver et al. (1994). The spectrum of the irradiance reaching the sample position was measured with a radiometer (Biospherical Instruments QSL-100 $4 \Pi$ collector). This spectrum of the xenon lamp was measured every $2 \mathrm{~nm}$ in triplicate and corrected for variations in the efficiency of the radiometer at different wavelengths (according to the specifications of the instrument). The accuracy of this excitation correction was examined by comparing the absorption and the corrected excitation fluorescence spectrum of pure chl $a$ in $90 \%$ acetone, which showed good agreement in their shapes (see Lutz et al. 1998 their Fig. 2). The spectra were then smoothed by taking a running average over $5 \mathrm{~nm}$ and corrected for variations between fluorescence of the cells in suspension and on filter (Lutz et al. 1998). The corrected fluorescence excitation spectra, $f_{c}(\lambda)$, reported here, are the averages of 2 measurements. The mean coefficient of variation for the duplicate values of $f_{c}(440)$ from 21 stations at the DCM was $17.9 \% \pm 15.1$. Spectra are shown

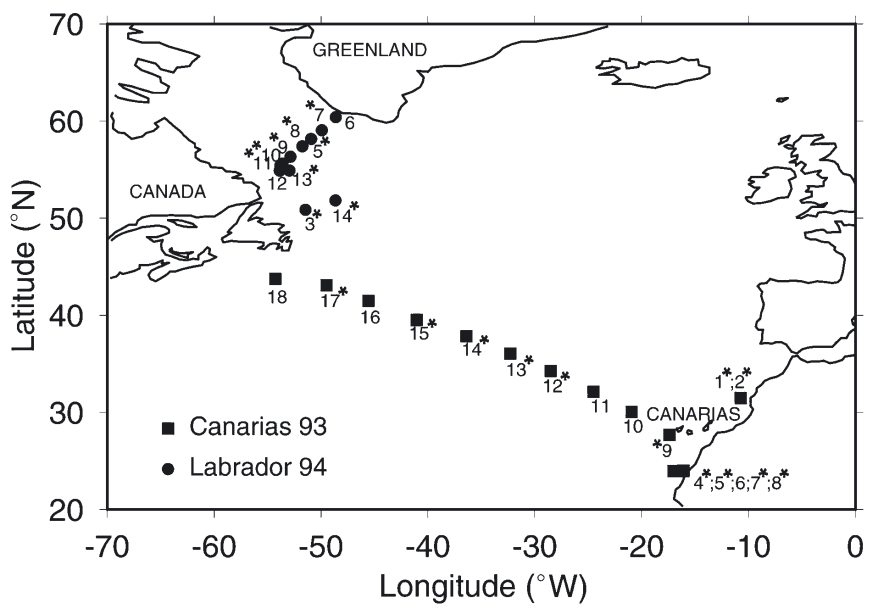

Fig. 1. Location of sampling stations. Asterisks indicate the stations where size fractionation was performed

between 400 and $600 \mathrm{~nm}$ because of calibration problems at the red end of the spectrum caused probably by scattered light from the glass fiber filters.

Absorption spectra. Optical densities of particulate matter were measured on board on a Beckmann DU-64 spectrophotometer using the filter technique (Yentsch 1962, Kishino et al. 1985). Absorption spectra of phytoplankton, $a_{p h}(\lambda)$, were obtained from optical densities after correcting for the path length amplification factor, transforming decimal to natural logarithms, adjusting for the volume filtered and the area of filtration, and subtracting detrital absorption (Lutz et al. 1998). The path length amplification factor was estimated applying the quadratic equation described by Mitchell (1990), but the coefficients required in this equation were modified to account for the effect of Prochlorococcus (Kyewalyanga et al. 1998, Lutz et al. 1998, Stuart et al. 1998). The modification involved assessment of the contribution of Prochlorococcus to the absorption by comparing the concentration of divinyl-chl $a$ to total chl $a$. The portion of absorption corresponding to Prochlorococcus was then corrected (for the amplification factor) using one set of coefficients appropriate for Prochlorococcus (Moore et al. 1995), and the rest of the absorption was corrected using the normal set of coefficients (Hoepffner \& Sathyendranath 1992). Detrital absorption was estimated using the approach described by Hoepffner \& Sathyendranath (1993). All absorption spectra reported here are the averages of 2 replicate measurements. The mean coefficient of variation for the duplicate values of $a_{p h}(440)$ from 21 stations at the DCM was $6.9 \% \pm 7.3$.

The proportion of $a_{p h}(\lambda)$ due solely to photoprotective (PP) pigments was estimated using the reconstruction method described by Bidigare et al. (1990b) as 
modified by Babin et al. (1996). This method is based on using an estimated shape for the specific absorption spectrum of PP pigments and scaling its magnitude according to the concentration of PP pigments in the sample (Bidigare et al. 1990b). This PP pigment absorption, $a_{P P}(\lambda)$, is then divided by the total phytoplankton spectrum (reconstructed using the specific coefficients and concentrations of all pigments present in the sample) and multiplied by the total measured phytoplankton spectrum (Babin et al. 1996). We finally estimated the percentage contribution by PP pigments to the total measured phytoplankton absorption at $440 \mathrm{~nm}$ as $\% a_{P P}(440)=100 \cdot a_{P P}(440) / a_{p h}(440)$.

Other measurements. PAR (photosynthetically available radiation, 400 to $700 \mathrm{~nm}$ ) was measured on deck with a radiometer (LI-COR LI-190) fitted with a $4 \pi$ collector. Irradiance at different depths was estimated from surface irradiance and the in vivo absorption and chl a values from discrete depths, according to the model proposed by Sathyendranath \& Platt (1988). CTD data were obtained using a Guildline CTD (Model 8705). Nitrate concentrations were measured using an Alpkem RFA autoanalyzer. Picophytoplankton composition was determined by flow cytometric analysis following the method described in Li (1994).

\section{RESULTS}

\section{Distribution of phytoplankton biomass}

To obtain a general understanding of the environmental conditions in the 2 areas of study, we analyzed the distribution of phytoplankton biomass (as chl a concentration) in the context of the main hydrographic features.

\section{Canarias cruise}

Some information on pigment and main hydrographic characteristics of the Central North Atlantic during the Canarias cruise has been reported (Olaizola et al. 1996, Waser et al. 2000). Only the data necessary for interpretation of our results are shown here. The concentration of chl a (Fig. 2) was low $\left(<0.2 \mathrm{mg} \mathrm{m}^{-3}\right)$ in the east (close to Canarias) and much higher in the west (The Grand Banks of Newfoundland). The DCM was greater in the east ( 80 to $100 \mathrm{~m})$ and shallower towards the west $(\sim 20$ to $30 \mathrm{~m})$. This distribution of phytoplankton abundance followed the distribution of nitrate concentration in the 0 to $100 \mathrm{~m}$ depth range

\section{Canarias station number}
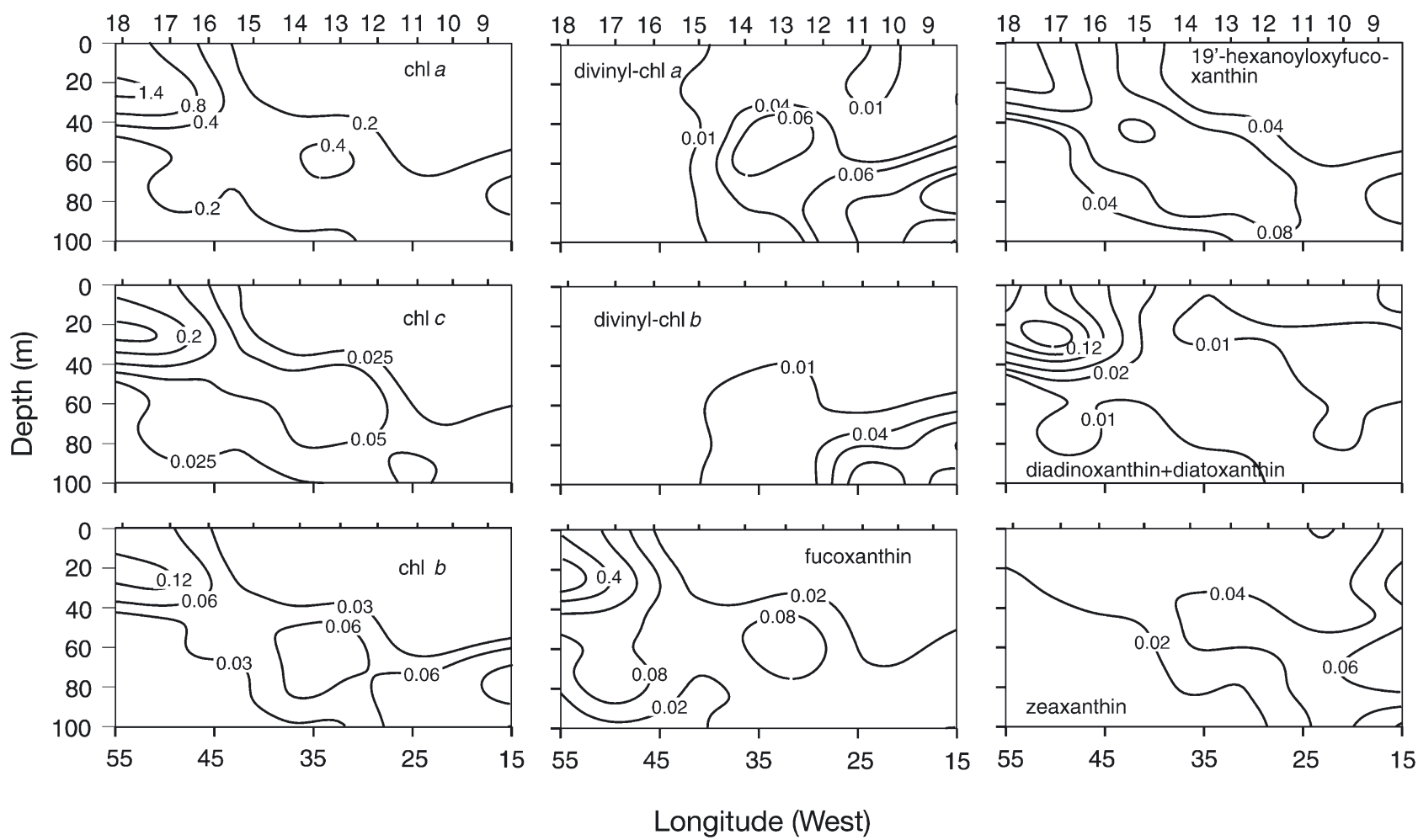

Fig. 2. Vertical distribution of main phytoplankton pigments $\left(\mathrm{mg} \mathrm{m}^{-3}\right)$ found during the Canarias transect 
(Fig. 3), which exhibited extremely low values $(<0.02 \mu \mathrm{M})$ at the surface in the warm subtropical waters (Fig. 3), and a deep nitracline, which showed increasing concentrations at shallower depths towards the west.

\section{Labrador cruise}

Chl a concentrations were higher in the top $\sim 40 \mathrm{~m}$ of the water column and reached maximum values close to the coasts of Labrador ( $>4 \mathrm{mg} \mathrm{m}^{-3}$ ) and Greenland $\left(>0.8 \mathrm{mg} \mathrm{m}^{-3}\right.$; Fig. 4). Nitrate concentrations throughout the 0 to $100 \mathrm{~m}$ depth range were high for the whole section (>5 $\mu \mathrm{M}$; Fig. 3). The hydrography of the Labrador Sea is complex (Lazier \& Wright 1993, Reynauld et al. 1995) and it has been reported that bloom formation in this area does not depend entirely on thermal stratification, but also on the dynamics of the ice melt (Head et al. 2000). The temperature section showed the lowest values, uniformly distributed with depth, close to the 2 ends of the transect (near the Labrador and Greenland shelves). The stability of the water col-

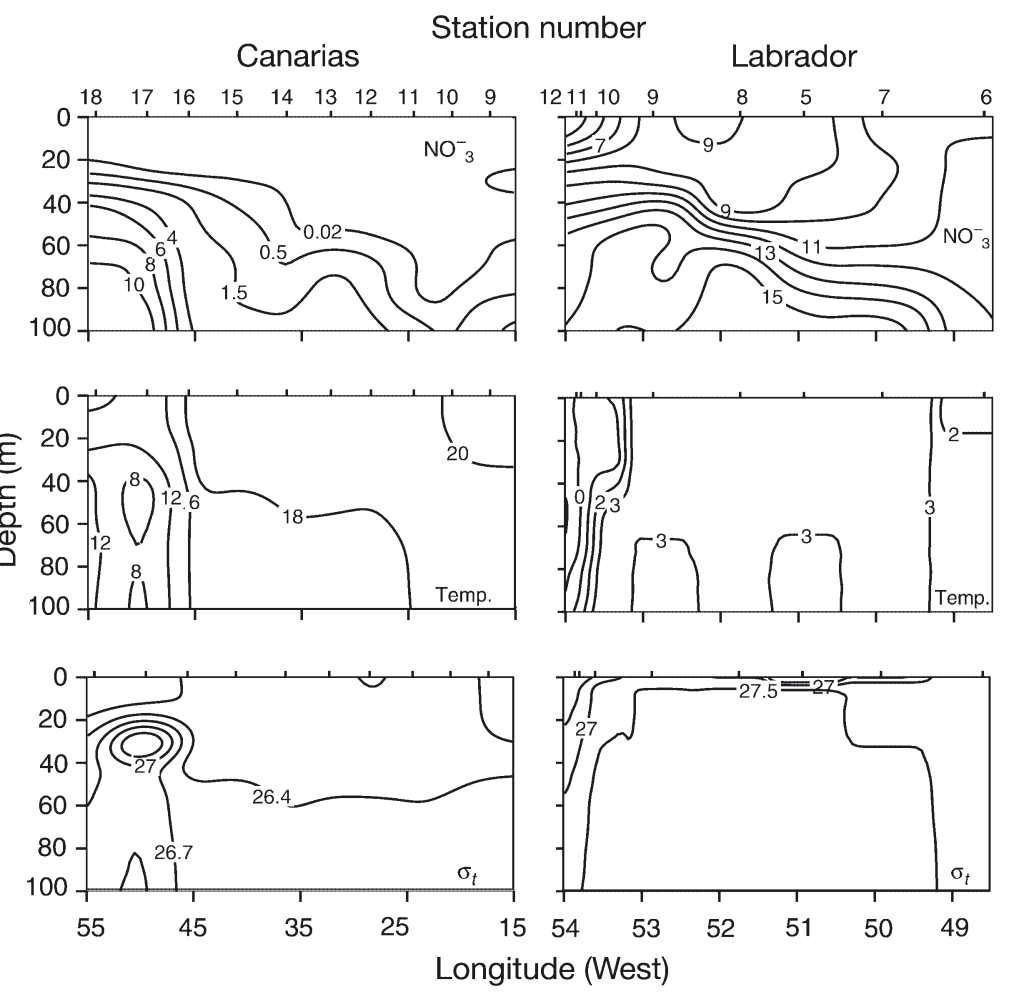

Fig. 3. Vertical distribution of nitrate concentration $\left(\mathrm{NO}_{3}{ }^{-}\right)$in $\mu \mathrm{M}$, temperature (Temp.) in ${ }^{\circ} \mathrm{C}$ and density as $\sigma_{t}$ for the Canarias and Labrador transects

\section{Labrador station number}
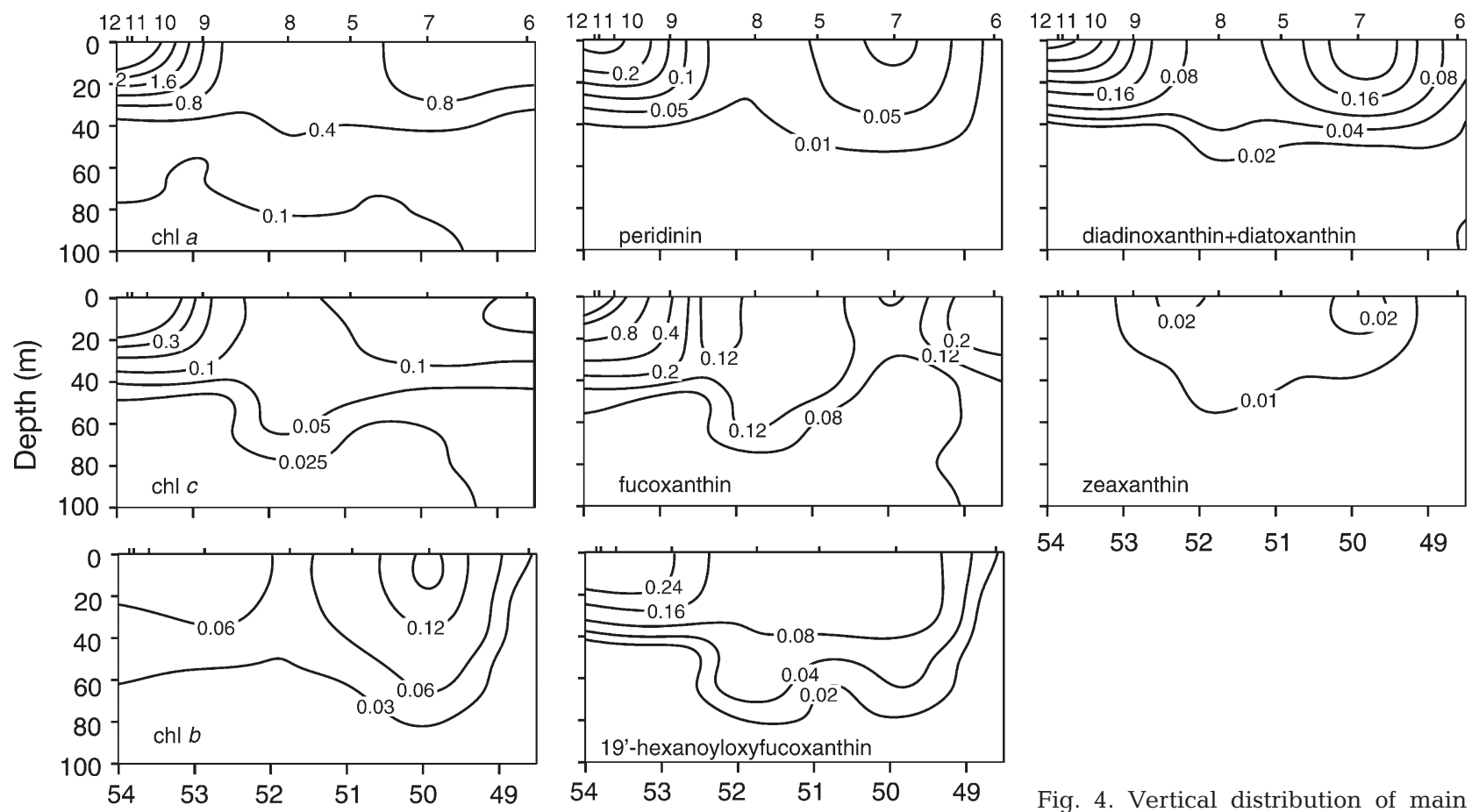

Longitude (West)

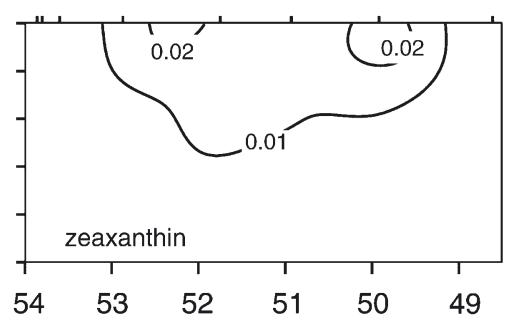

Fig. 4. Vertical distribution of main phytoplankton pigments $\left(\mathrm{mg} \mathrm{m}^{-3}\right.$ ) found during the Labrador transect 
umn was high in the upper few meters along the transect, as shown in the $\sigma_{\mathrm{t}}$ profile, due to the melting of ice over the shelves and subsequent advection into the central region.

\section{Biogeochemical provinces}

According to their locations, the stations sampled belong to different biogeochemical provinces (Longhurst 1998). Thus, for the Canarias cruise, Stns 8 and 7 were in the Eastern Canary Coastal Province (South Moroccan Coastal waters), whereas the nearby shelf Stns 4, 5 and 6 together with Stns 1, 2, 9, 12, 13, 14 and 15 were located on the North Atlantic Subtropical Gyres (East and West) Provinces; Stn 17 corresponded to the Northwest Atlantic Shelves Province (The Grand Banks of Newfoundland). On the Labrador cruise, Stns 14 and 3 were on the Northwest Atlantic Shelves Province (Newfoundland Shelf); Stns 13, 11 and 10 were on the Boreal-Polar Province (Labrador Shelf); and Stns 9, 8, 5 and 7 were in the Atlantic Arctic Province (Central Labrador Sea). Note that in tables and figures, stations are ordered according to their location in biogeochemical provinces.

\section{Distribution of main pigments}

An overview of the distribution of the main taxonomic groups along the transects could be inferred from the pigment composition of the samples. In this work, what is referred to as chl $a$ is the sum of 'regular' chl $a$ and divinyl-chl $a$; similarly chl $b$ is the sum of 'regular' chl $b$ and divinyl-chl $b$. The distributions of the most abundant pigments across the Central North Atlantic (Canarias cruise) and across the Labrador Sea (Labrador cruise) are shown in Figs. $2 \& 4$.

\section{Canarias}

The pattern of chl $c\left(c_{1}+C_{2}\right)$ distribution followed that of chl $a$. Chl $b$ distribution was also similar to that of chl a, but it showed a more conspicuous deep maximum on the east side of the transect (Fig. 2). Divinyl-chls a and $b$ were restricted to warm subtropical waters with concentrations increasing with increasing depth. Divinyl-chl $b$ was only detected below $\sim 40 \mathrm{~m}$. The distribution of fucoxanthin followed that of $\operatorname{chl} a$ and varied in concentration by a factor of $>20$, whereas that of 19'-hexanoyloxyfucoxanthin followed a similar pattern, but showed a smaller concentration range (factor of $\sim 3$ ). Peridinin (distribution not shown for the Canarias cruise) was only detected at 1 location
(Stn 17) on the Newfoundland Shelf. The diadinoxanthin+diatoxanthin combination had its highest concentrations close to the surface, with a maximum in the west. Zeaxanthin showed high concentrations in the east decreasing towards the west.

\section{Labrador}

The distribution of $\operatorname{chl} c\left(c_{1}+C_{2}\right)$ followed that of chl $a_{1}$ whereas chl $b$ showed a marked maximum at Stn 7 and occurred throughout the center of the transect (Fig. 4). Divinyl-chlorophylls were not detected at any of the stations on this transect. Fucoxanthin distribution was similar to that of chl $a$ and varied in concentration by a factor of $\sim 7$, and 19'-hexanoyloxyfucoxanthin was found at all stations and varied in concentration by a factor of $\sim 10$. Peridinin occurred in the top $\sim 40 \mathrm{~m}$ of the water column, with maximum concentrations at the surface near the Labrador shelf and a secondary maximum at the surface at Stn 7 . The distribution of diadinoxanthin+diatoxanthin followed that of $\operatorname{chl} a$, but showed a maximum at Stn 7. Zeaxanthin occurred at low levels $\left(<0.02 \mathrm{mg} \mathrm{m}^{-3}\right)$ close to the surface in the central Labrador Sea.

\section{Distribution of the main phytoplankton groups at the DCM}

The predominant algal groups at the DCM (Table 1; see selected stations marked with an asterisk on Fig. 1) were inferred from the ratios of the main pigments to total chl a. A more detailed study of the picophytoplankton distribution at stations from the Canarias cruise using flow cytometer data was reported by Li (1995). The use of accessory pigments, although it has some limitations (i.e. many pigments are not unique to one particular class; Jeffrey \& Vesk 1997), has proven to give an adequate description of the most probable composition of the phytoplankton community (e.g. Gieskes et al. 1988, Mackey et al. 1996). A detailed description of pigments present in different taxonomic groups can be found in the literature (e.g. Rowan 1989, Jeffrey \& Vesk 1997). The main phytoplankton pigments (besides chl a), which could be used to infer algal composition in these samples, are listed in Table 2. Divinyl-chlorophylls were used as marker pigments for Prochlorococcus. Phycoerythrin, which was estimated here by its fluorescence emission, was considered as an indicator of the presence of Synechococcus (cyanobacteria) since no alloxanthin, the marker for cryptophytes, was detected in the samples. In addition, the presence of Synechococcus was confirmed by flow cytometry. Carotenoids can be divided into PS and PP types (Siefermann-Harms 1987). In 
Table 1. Main phytoplankton groups found in the whole sample at the deep chlorophyll maximum (DCM) at selected stations from the 2 cruises (see Fig. 1). Different groups were identified by their characteristic pigment composition determined by HPLC and by flow cytometry in the particular case of cyanobacteria (Synechococcus and Prochlorococcus). ++: abundant; ++?: probably present in abundance, but lacks pigments exclusive to particular algal types; +: present; + ?: probably present, but lacks pigments exclusive to particular algal types; + L: present in low concentrations

\begin{tabular}{|c|c|c|c|c|c|c|c|c|c|c|c|c|c|}
\hline \multirow[b]{2}{*}{ Phytoplankton group } & \multicolumn{13}{|c|}{ Canarias stations } \\
\hline & 8 & 7 & & 5 & 4 & 1 & 2 & 9 & 12 & 13 & 14 & 15 & 17 \\
\hline Synechococcus & & ++ & & ++ & ++ & + & + & ++ & + & + & + & + & \\
\hline Prochlorococcus & & + & & + & + & ++ & ++ & + & + & + & + & & \\
\hline Chlorophytes $^{\mathrm{a}}$ & & $+?$ & & $+?$ & $+?$ & $+?$ & $+?$ & $+?$ & $+?$ & $+?$ & $+?$ & & \\
\hline Haptophytes & ++ & + & & + & + & + & + & + & + & ++ & ++ & ++ & ++ \\
\hline Diatoms & ++ ? & + ? & & $+?$ & $+?$ & + ? & $+?$ & + ? & $+?$ & $+?$ & $+?$ & $+?$ & ++ ? \\
\hline \multirow[t]{2}{*}{ Dinoflagellates } & & & & & & & & & & & & & ++ \\
\hline & \multicolumn{13}{|c|}{ Labrador stations } \\
\hline Phytoplankton group & 14 & & 3 & & 13 & 11 & & 10 & 9 & 8 & & 5 & 7 \\
\hline Synechococcus & $+\mathrm{L}$ & & $+\mathrm{L}$ & & $+\mathrm{L}$ & $+\mathrm{L}$ & & $+\mathrm{L}$ & $+\mathrm{L}$ & $+\mathrm{L}$ & & $+\mathrm{L}$ & $+\mathrm{L}$ \\
\hline \multicolumn{14}{|l|}{ Prochlorococcus } \\
\hline Chlorophytes & & & & & & & & & & & & ++ & ++ \\
\hline Haptophytes & + & & + & & + & + & & + & ++ & ++ & & ++ & ++ \\
\hline Diatoms & $++?$ & & $++?$ & & $++?$ & $+?$ & & $++?$ & + ? & $+?$ & & $+?$ & $+?$ \\
\hline Dinoflagellates & & & & & + & + & & + & + & & & + & + \\
\hline
\end{tabular}

these samples, the most commonly found PS carotenoids were fucoxanthin, peridinin, 19'-hexanoyloxyfucoxanthin and 19'-butanoyloxyfucoxanthin, and the most common PP carotenoids were zeaxanthin, diadinoxanthin, diatoxanthin, $\alpha$-carotene and $\beta$-carotene. The concentrations of diadinoxanthin and diatoxanthin are reported as the sum (diadinoxanthin+diatoxanthin) of the two as they can be rapidly interconverted; therefore, we could not tell how much of each would have been present in the original water sample (Demmig-Adams 1990, Demers et al. 1991, Olaizola \& Yamamoto 1994). The amounts of $\alpha$ - and $\beta$-carotenes are also reported together as the sum $\alpha-+\beta$-carotenes since these pigments were found in very low concentrations.

During the Canarias cruise, the phytoplankton populations at Stns 1, 2, 4, 5, 7, 9, 12, 13 and 14 were composed of a mixture, in different proportions, of Prochlorococcus, Synechococcus, haptophytes (ex Prymnesiophyta; Edvardsen et al. 2000) and probably, chlorophytes and diatoms. At Stns 4, 5, 7 and 9, Synechococcus seemed to be dominant. At Stns 1 and 2, Prochlorococcus was dominant, and at Stns 13 and 14

Table 2. Main pigments found in the samples which could be used to identify main phytoplankton groups present in the 2 cruises (from Rowan 1989, Jeffrey \& Vesk 1997)

\begin{tabular}{|c|c|c|c|c|c|c|}
\hline \multirow[t]{2}{*}{ Pigments } & \multicolumn{6}{|c|}{ Phytoplankton groups } \\
\hline & Diatoms & Dinoflagellates & Haptophytes & Chlorophytes & Prochlorococcus & Synechococcus \\
\hline Chl $c_{1}+C_{2}$ & + & + & + & & & \\
\hline $\mathrm{Chl} C_{3}$ & & $t^{\mathrm{a}}$ & + & & & \\
\hline Chl $b$ & & & & + & + & \\
\hline Divinyl-chl a & & & & & + & \\
\hline Divinyl-chl $b$ & & & & & + & \\
\hline Fucoxanthin & + & $t^{\mathrm{a}}$ & + & & & \\
\hline 19'-hexanoyloxyfucoxanthin & & $t^{\mathrm{a}}$ & + & & & \\
\hline 19'-butanoyloxyfucoxanthin & & $t^{\mathrm{a}}$ & + & & & \\
\hline Peridinin & & + & & & & \\
\hline Diadinoxanthin & + & + & + & & & \\
\hline Diatoxanthin & + & + & + & & & \\
\hline Zeaxanthin $^{\mathrm{b}}$ & & & & + & + & + \\
\hline Phycobilins & & & & & & + \\
\hline
\end{tabular}


haptophytes dominated the phytoplankton community. Stn 15 showed a mixture of haptophytes, Synechococcus and probably diatoms, with haptophytes as the dominant group. Stn 8 (off Morocco) was dominated by diatoms and haptophytes, and Stn 17 (on the Newfoundland Shelf) was dominated by diatoms, dinoflagellates and haptophytes.

In the Labrador Sea, all stations showed a mixture of mainly diatoms and haptophytes, plus dinoflagellates at Stns 5, 7, 9, 10, 11 and 13. Flow cytometry and phycoerythrin fluorescence also indicated that Synechococcus was present, although in only minor concentrations in comparison with the values found at subtropical stations on the Canarias cruise (Li 1998). Stations in the central Labrador Sea (Stns 5, 7, 8 and 9) seemed to be dominated by haptophytes and also chlorophytes (Stns 5 and 7), whereas stations on the Labrador and Newfoundland shelves (Stns 3, 10, 11, 13 and 14) were apparently dominated by diatoms and haptophytes. The presence of the haptophyte Phaeocystis sp., which may contain large amounts of fucoxanthin, has been reported in the Labrador Sea by Stuart et al. (2000).

\section{Relative abundance of main pigments at the surface and DCM}

For a selection of representative stations (marked by an asterisk in Fig. 1), we assessed the changes in the relative amounts of PS and PP carotenoids with irradiance at different depths. We worked with log-transformed irradiance since it is known that irradiance decreases in an approximately exponential fashion with depth in the ocean (Kirk 1994). Significant correlations between PP carotenoids/chl $a$ and log-irradiance $\left(\mathrm{r}^{2}=\right.$ 0.46, p < 0.0000001) and PS carotenoids/chl $a$ and logirradiance $\left(\mathrm{r}^{2}=0.27, \mathrm{p}<0.0000001\right)$ were observed for all samples (all selected stations and depths; Fig. 5). To differentiate changes in pigment composition due to changes in irradiance with depth, we grouped separately samples from the surface and DCM. The use of Wilcoxon's matched pairs test showed that on average (from all selected stations) the ratio of PP carotenoids/chl a was significantly higher at the surface than at the DCM ( $p<0.0001)$, whereas the average ratio of PS carotenoids/chl a was significantly higher at the DCM than at the surface $(p<0.002)$. Individual analysis of the distribution of the main carotenoids, applying again the Wilcoxon's test, showed that the ratio of fucoxanthin to chl a was significantly higher at the DCM than at the surface $(\mathrm{p}<0.05)$ as expected from its PS role, whereas the ratios of the main PP carotenoids (zeaxanthin and diadinoxanthin+diatoxanthin) to chl a were significantly higher at the surface than at the DCM ( $p<0.02$ for the ratio zeaxanthin/chl $a$ and $p<$
0.0002 for the ratio diadinoxanthin+diatoxanthin/chl a). On the other hand, the ratio of 19'-hexanoyloxyfucoxanthin to chl a was not significantly different at the surface than at the DCM ( $p>0.4)$, despite the presumed PS function of this carotenoid.

Variation with depth was also found in the level of phycoerythrin (relative fluorescence emission at $570 \mathrm{~nm}$ ) per Synechococcus cell (Fig. 6). For the pooled data from 3 depths (surface, DCM and 1 depth selected from below the DCM), the relationship between relative fluorescence at $570 \mathrm{~nm}$ and the number of Synechococcus per liter showed a coefficient of determination $\left(\mathrm{r}^{2}\right)$ of 0.64 , which was significantly different from zero $(\mathrm{p}<0.0001$ ). The fit yielded a slope of $\sim 0.14$. If samples from the surface and from the DCM were analyzed separately, the coefficients of determination improved $\left(\mathrm{r}^{2}=\sim 0.73\right.$ for the surface and $\mathrm{r}^{2}=\sim 0.74$ for the DCM, both significantly different from zero, p < 0.0001 ) and the slopes were also different (slope = $\sim 0.09$ for the surface and $\sim 0.21$ for the DCM), indicating a higher concentration of phycoerythrin per cell at the DCM. This depth-related difference was also found in vertical profiles of cellular phycoerythrin fluorescence measured by flow cytometry (Li \& Wood 1988). It should be noted, however, that some of the variability in the fluorescence emission could derive from changes in the relative amounts of phycoerythrobilin and phycourobilin present in different strains of Synechococcus (Vernet et al. 1990, Wood et al. 1998).

\section{Variability in the shape of the absorption spectra}

To investigate the effect of pigment composition and the packaging effect (due either to changes in species composition or to photoacclimation) on the absorption spectrum, we analyzed the relationships between
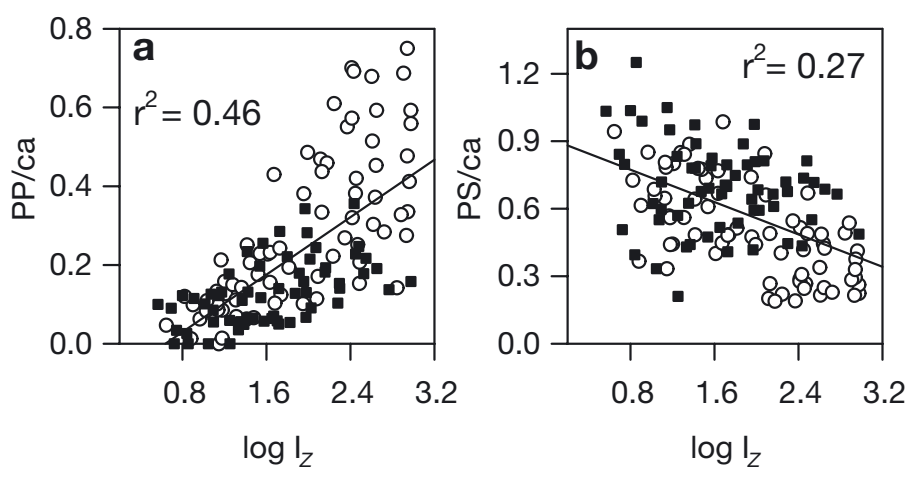

Fig. 5. Regressions between (a) the ratio of photoprotective pigments to chl a (PP/ca) and the logarithm of irradiance at each depth and (b) the ratio of photosynthetic pigments to $\mathrm{chl}$ a (PS/ca) and the logarithm of irradiance at each depth. Samples are from selected stations (see Fig. 1) for all depths, for the Canarias ( $(0)$ and Labrador ( $\mathbf{\square}$ cruises 


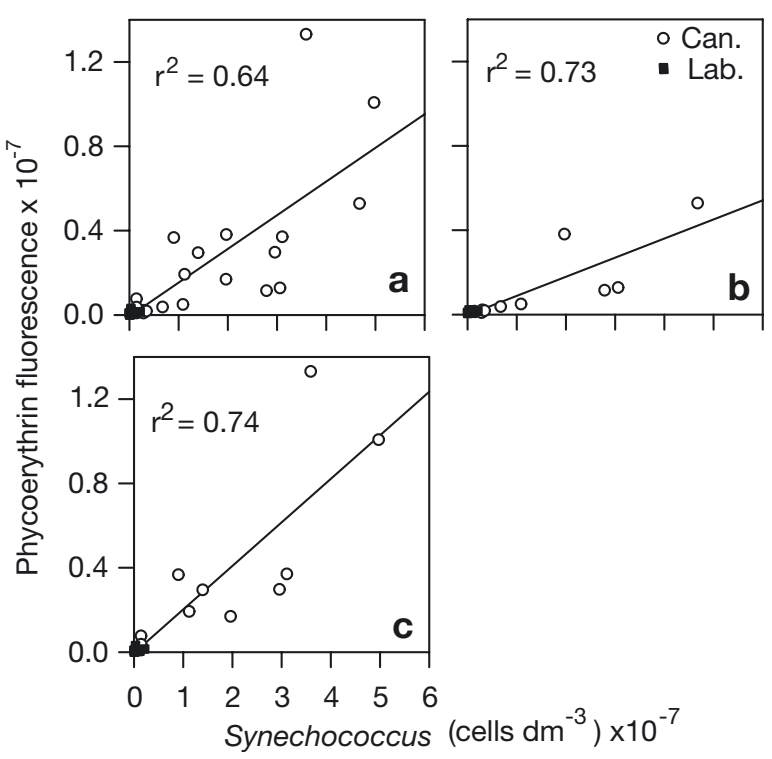

Fig. 6. Regressions between fluorescence emission by phycoerythrin (emission: $570 \mathrm{~nm}$, excitation: $520 \mathrm{~nm}$ ) in relative units and the concentration of Synechococcus cells in selected stations (see Fig. 1). (a) Pooled data from 3 depths (surface, deep chlorophyll maximum [DCM] and one chosen depth

below the DCM), (b) surface samples, (c) DCM samples

absorption at different pairs of wavelengths and the ratios of main pigments to chl $a$. The ratio $a_{p h}(440) /$ $a_{p h}(676)$ showed a significant positive correlation with the ratio of PP pigments to chl a concentrations $\left(\mathrm{r}^{2}=\right.$ $\sim 0.63$; significant for $\mathrm{p}<0.0000001$; Fig. 7). Among the $\mathrm{PP}$ pigments present in the samples, the ratio of zeaxanthin to chl a seemed to account for most of the variation in $a_{p h}(440) / a_{p h}(676)\left(\mathrm{r}^{2}=\sim 0.60\right.$; significant for $\mathrm{p}<0.0000001)$, whereas the ratio diadinoxanthin+diatoxanthin to chl a had a non-significant $\left(\mathrm{r}^{2}=\sim 0.03, \mathrm{p}>\right.$ $0.05)$ correlation with $a_{p h}(440) / a_{p h}(676)$. The ratio of PS to chl a concentrations showed a significant negative correlation with $a_{p h}(440) / a_{p h}(676)\left(\mathrm{r}^{2}=\sim 0.32\right.$; significant for $\mathrm{p}<0.0000001)$. Among the PS carotenoids, the ratio of fucoxanthin to chl $a$ also had a significant negative correlation with the ratio $a_{p h}(440) / a_{p h}(676)\left(\mathrm{r}^{2}=\right.$ $\sim 0.47$; significant for $\mathrm{p}<0.0000001$ ), whereas the ratio of 19'-hexanoyloxyfucoxanthin to chl a showed a significant positive correlation with $a_{p h}(440) / a_{p h}(676)$ $\left(\mathrm{r}^{2}=\sim 0.16\right.$; significant for $\left.\mathrm{p}<0.00001\right)$.

To evaluate the effect of the percentage absorption by PP pigments at $440 \mathrm{~nm}, \% a_{P P}(440)$, at different depths, we calculated the average contribution of PP pigment absorption at $440 \mathrm{~nm}$ for the pooled data (all depths) as well as for the surface and the DCM samples. As expected, surface samples had the highest \% $a_{P P}(440)$ : on average, $\sim 24 \%$ (coefficient of variation, CV $45.70 \%$ ) of the absorption at $440 \mathrm{~nm}$ at the surface was due to PP pigments. At the DCM, absorption by PP pigments contributed $\sim 14 \%$ (CV 50.96\%) of total phytoplankton absorption at $440 \mathrm{~nm}$. On the pooled data, absorption by PP pigments accounted for $\sim 15 \%$ (CV $72.77 \%$ ) of total phytoplankton absorption at $440 \mathrm{~nm}$.

The relative abundance of Synechococcus was related to the ratio $a_{p h}(555) / a_{p h}(623)$. Absorption at $555 \mathrm{~nm}$ is close to the maximum of absorption by phycoerythrin (Rowan 1989), and absorption at $623 \mathrm{~nm}$ corresponds to a peak of absorption by chl a in vivo (Hoepffner \& Sathyendranath 1991). This ratio $a_{p h}(555) / a_{p h}(623)$ was correlated $\left(\mathrm{r}^{2}=\sim 0.4\right.$; significantly different from $0, \mathrm{p}<0.0001$ ) with the ratio of the concentration of Synechococcus cells to total chl a concentration (Fig. 8).
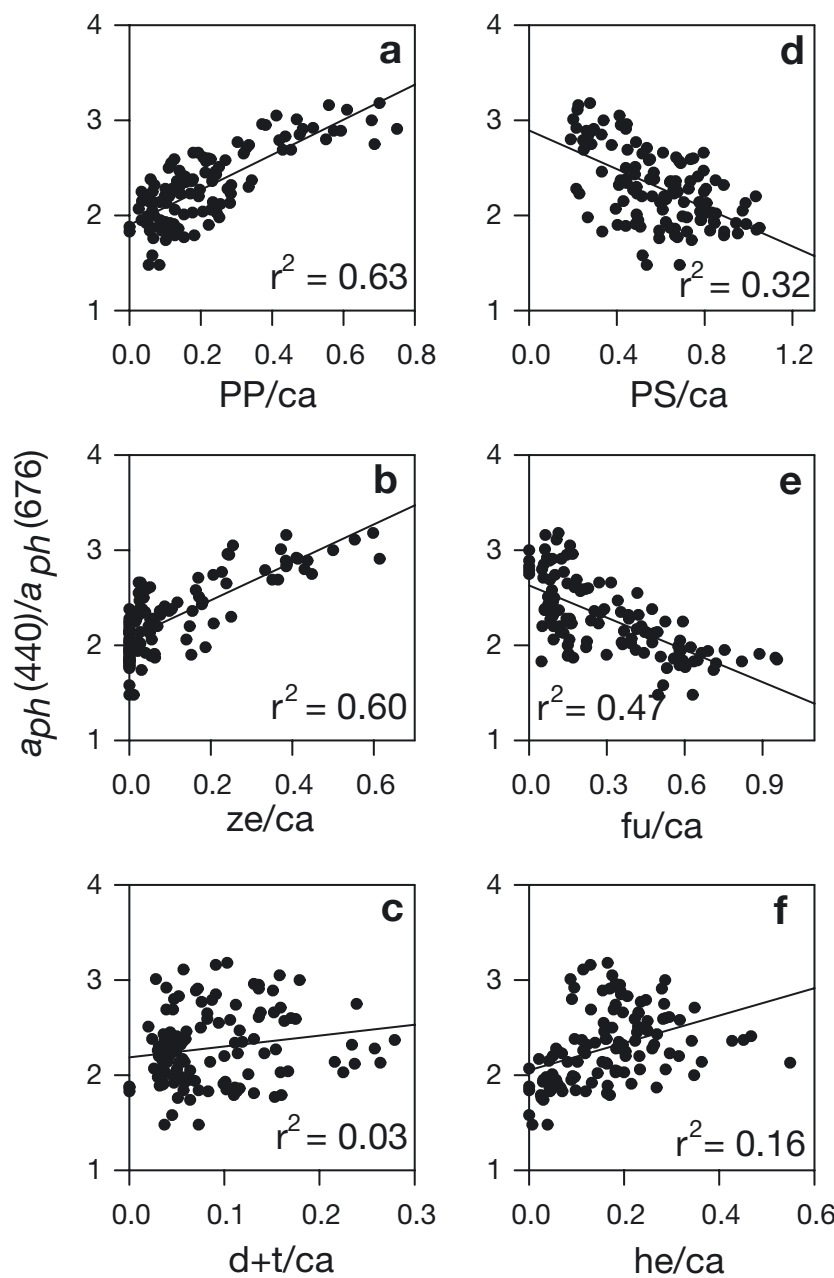

Fig. 7. Regressions between the ratio of absorption at $440 \mathrm{~nm}$ to absorption at $676 \mathrm{~nm}\left[a_{p h}(440) / a_{p h}(676)\right]$ and (a) the ratio of the sum of photoprotective pigments to chl a (PP/ca), (b) the ratio of zeaxanthin to $\mathrm{chl}$ a (ze/ca), (c) the ratio of diadinoxanthin+diatoxanthin to $\mathrm{chl} a(\mathrm{~d}+\mathrm{t} / \mathrm{ca})$, (d) the ratio of the sum of photosynthetic pigments to chl a (PS/ca), (e) the ratio of fucoxanthin to chl a (fu/ca), and (f) the ratio of 19'hexanoyloxyfucoxanthin to chl a (he/ca) 


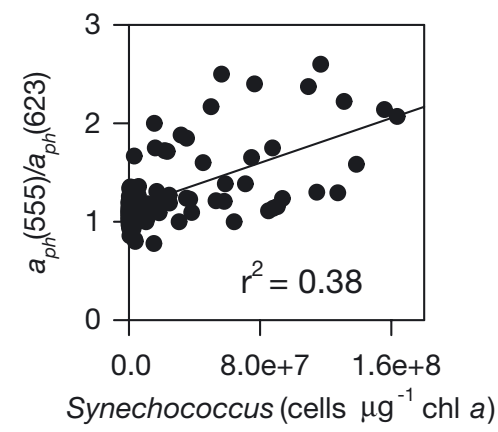

Fig. 8. Regression between the ratio of absorption at $555 \mathrm{~nm}$ to absorption at $623 \mathrm{~nm}\left[a_{p h}(555) / a_{p h}(623)\right]$ and the number of Synechococcus cells per concentration of $\mathrm{chl} a$

\section{Characteristics of phytoplankton in different size fractions}

To assess the contribution of small and large cells to the total chl $a$, absorption and fluorescence, we analyzed the properties of these variables in 2 size fractions $(<2 \mu \mathrm{m}$ and $>2 \mu \mathrm{m})$. Size fractionation was performed at 3 depths (surface, DCM, below DCM) at 21 stations (marked with an asterisk on Fig. 1). However, for this analysis, we used only samples from the DCM, since several of the surface and deep (below the DCM) samples in oligotrophic areas had extremely low phytoplankton concentrations, which resulted in noisy optical measurements, close to, or below, the limit of detection of the instruments.
Contribution of different size fractions to total biomass and optical properties of phytoplankton

To estimate the contribution of small and large cell sizes to the measured phytoplankton variables in the whole area, we calculated the average chl a concentration, the absorption coefficient at $440 \mathrm{~nm}, a_{p h}(440)$, and the fluorescence excitation at $440 \mathrm{~nm}, f_{c}(440)$, for 2 size-fractions: $<2 \mu \mathrm{m}$ (small) and $>2 \mu \mathrm{m}$ (large) as well as for the total. The large fraction was estimated by subtracting the value of the small fraction from that of the total. These estimates (Table 3) show that the small fraction accounted for $\sim 18 \%$ of the average chl a concentration, but the contributions to total optical properties, $a_{p h}(440)$ and $f_{c}(440)$, were higher ( 35 and $\sim 44 \%$, respectively). The average specific absorption coefficient at $440 \mathrm{~nm}$ for the large fraction was $47 \%$ lower than that for the small fraction (data not shown). The small fraction had a lower degree of variability in the average chl a concentration and $a_{p h}(440)$ than did the large fraction or the total, whereas variability in $f_{c}(440)$ was comparable for both fractions and the total.

To evaluate the effect of variations caused by changes in the composition of the phytoplankton assemblages (at different stations), we calculated the percentage contribution of the measured chl a concentration, $a_{p h}(440)$, and $f_{c}(440)$ for the $<2 \mu \mathrm{m}$ fraction to those measured for the total phytoplankton sample. At stations in oligotrophic subtropical waters during the Canarias cruise (i.e. Stns: 1, 2, 4, 5, 9, 12, 13, 14 and 15), picophytoplankton contributed between 40 and $100 \%$

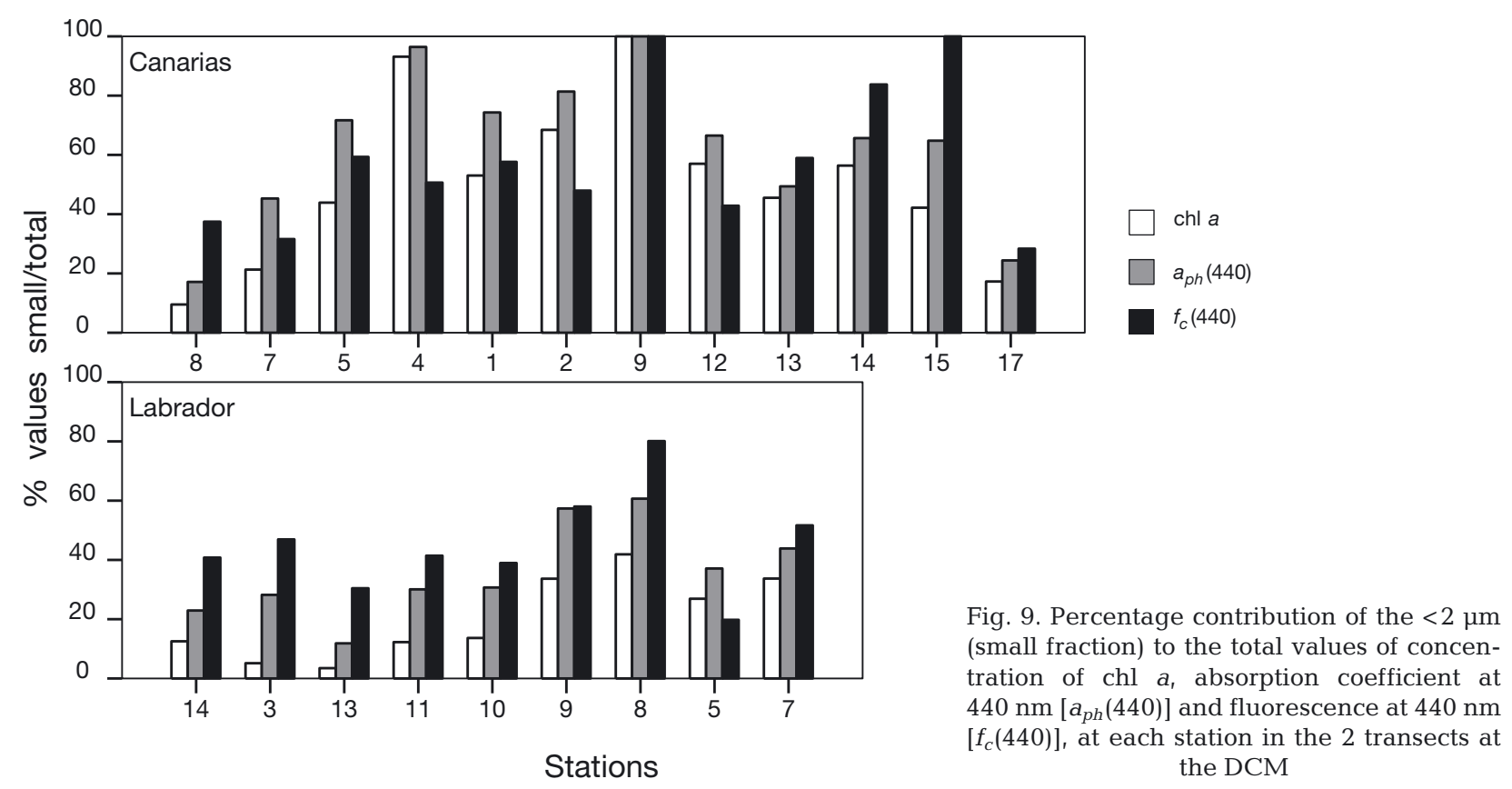


of the total chl $a$ and $a_{p h}(440)$, and this contribution decreased towards eutrophic areas close to Moroccan Coast (Stns 8 and 7) and the Newfoundland Shelf (Stn 17; Fig. 9). On the other hand, the contribution of picophytoplankton to total $f_{C}(440)$ showed a different pattern (Fig. 9). At most of the oligotrophic stations (Stns 1, 2, 4, 5, 12 and 13), the percentage contribution of the small fraction to total $f_{C}(440)$ was lower than the contribution of the same fraction to total $a_{p h}(440)$, whereas the opposite effect was observed for the remaining stations. In the Labrador Sea, picophytoplankton contributed between 27 and $42 \%$ of the total chl a concentration and up to $60 \%$ of $a_{p h}(440)$ at the central Labrador Sea (Stns 7, 5, 8 and 9). The small fraction contributed much less at stations located in the Labrador Current (Stns 3, 10, 11, 13 and 14). Except for Stn 5, where the contribution to fluorescence was lower than that to absorption, picophytoplankton represented a significant portion of total fluorescence at $440 \mathrm{~nm}(\sim 40$ to $80 \%)$.

Variability in the absorption and fluorescence excitation spectral shapes in different size fractions

To study the variations in the spectral shapes of the 2 optical properties measured, we normalized the spectra at $623 \mathrm{~nm}$ in the case of absorption, $a_{p h}^{n}(\lambda)$, and $600 \mathrm{~nm}$ in the case of fluorescence, $f_{C}{ }^{n}(\lambda)$. It is known that chls $c_{1}, c_{2}$ and $c_{3}$ absorb at $623 \mathrm{~nm}$ in vitro (Jeffrey et al. 1997); however, it could be expected that their absorption in vivo should be shifted towards the red (e.g. $\sim 636 \mathrm{~nm}$ according to Bidigare et al. $1990 b_{;} \sim 635 \mathrm{~nm}$ in isolated pigmentprotein complexes according to Johnsen et al. 1997). Despite the possible interference by chl $c$ absorption, Stuart et al. (1998) found that in natural samples from various environments (Arabian Sea, coast of Vancouver Island), $623 \mathrm{~nm}$ was the wavelength least affected by the packaging effect. Hence, we chose $623 \mathrm{~nm}$ for the normalization of the absorption spectra. The average $a_{p h}^{n}(\lambda)$ for the large fraction showed the highest degree of flattening, for both the blue and red peaks, followed by the total, and then the small fraction (Fig. 10). The small fraction showed the highest coefficients of variation (Fig. 10), whereas the coefficients of variation for the large fraction and the total were of similar magnitudes at all wavelengths. This might have been in part because there were larger errors in the determination of absorption for the small fraction, which had the lowest concentrations on the filters, but it might also indicate a real effect, with higher variability in spectral shapes of absorption in picophytoplankton species than in larger species. Fluorescence excitation spectra were normalized at $600 \mathrm{~nm}$, since this was the longest available wavelength. In this case again, the flattening effect for the blue peak affected the large fraction and the total more than the small fraction (Fig. 10). The coefficients of variation for the different fractions showed a similar pattern, although the large fraction had the highest variability in the blue part of the spectrum $(\sim 440$ to $490 \mathrm{~nm})$, whereas the small fraction had the highest variations in the green part of the spectrum ( 558 nm; Fig. 10).
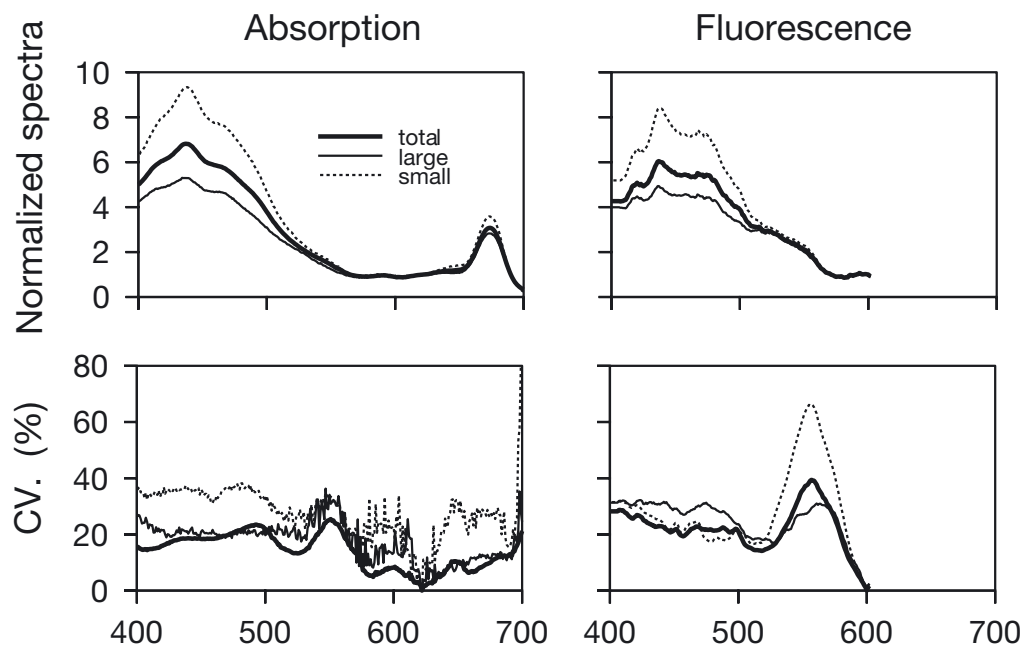

\section{Wavelength $(\mathrm{nm})$}

Fig. 10. Variations in the shape of the absorption and fluorescence excitation spectra for the 2 size fractions: $>2 \mu \mathrm{m}$ (large) and $<2 \mu \mathrm{m}$ (small), and for the total. These are averages of spectra from the DCM from 21 selected stations (see Fig. 1). Absorption spectra are normalized at $623 \mathrm{~nm}$ and fluorescence excitation spectra are normalized at $600 \mathrm{~nm}$. The coefficients of variation $(\mathrm{CV})$ for each spectrum are shown in the bottom panel 


\section{DISCUSSION}

\section{Photoadaptation and photoacclimation of phytoplankton populations}

Many studies have addressed the 'paradox' (Hutchinson 1961) or 'unpredictability' (Hulburt 1983) of phytoplankton distribution in the ocean. The main factors reported to affect the abundance and composition of phytoplankton communities in the ocean are: turbulence, light climate, nutrient availability and grazing pressure (e.g. Hutchinson 1961, Margalef 1978, Hulburt 1983, Kiørboe 1993, Smetacek 1998). Nevertheless, in order to simplify the study of phytoplankton composition in the ocean, it would be desirable to find environmental indicators of the presence of particular taxonomic groups. In this study, we analyzed the relationship between the distribution of different phytoplankton groups and their photoadaptation to the light environment. The main phytoplankton groups, inferred from their pigment composition, were distributed following general trends described in previous studies (e.g. Hulburt 1983, Malone 1980, Chisholm et al. 1992, Wood 1985, Wood et al. 1998). Synechococcus and Prochlorococcus dominated the phytoplankton biomass (as chl a) in clear oligotrophic waters, whereas diatoms and dinoflagellates dominated the biomass in turbid eutrophic waters (Figs. $2 \& 4$, Table 1). Haptophytes were the most ubiquitous group and were present in all types of environment, as was reported in another survey crossing the North Atlantic (Hulburt 1983).

Diatoms and dinoflagellates prevailed in shelf waters (and mainly in middle to high latitude waters), where average irradiance is lower than in subtropical regions (Figs. $2 \& 4$, Table 1 ). These types of algae can dramatically increase their levels of PS carotenoids at low irradiances (Falkowski 1983, Richardson et al. 1983, Falkowski \& La Roche 1991) and they photoacclimate to high irradiances by increasing the levels of PP pigments.

The predominance of Synechococcus and Prochlorococcus in blue subtropical waters (Figs. $2 \& 4$, Table 1) is a good example of photoadaptation to the prevailing light conditions. These species are known to possess high concentrations of the PP pigment zeaxanthin (cf. Figs. 5 \& 7), which can vary between 40 and $200 \%$ of the intracellular concentration of chl a (Kana et al. 1988, Veldhuis \& Kraay 1990). Moreover, it has been shown that these groups achieve this modulation not by changing the intracellular concentrations of zeaxanthin with changes in irradiance, but by changing the concentrations of chl a or divinyl-chl a (Kana et al. 1988, Veldhuis \& Kraay 1990, Lutz et al. 2001). At low light, as well as increasing the intracellular concentration of chl a, Synechococcus also increases the levels of phycobilins (Glover et al. 1985, Li \& Wood 1988; our Fig. 6) and Prochlorococcus increases the concentration of divinyl-chl $b$ (Veldhuis \& Kraay 1990, Moore et al. 1995; our Fig. 5).

The ubiquitous distribution of haptophytes (Figs. 2 \& 4, Table 1) might be, in part, the result of their varied pigment composition. Haptophytes contain different types of fucoxanthin-related carotenoids: fucoxanthin, 19' -hexanoyloxyfucoxanthin and 19'-butanoyloxyfucoxanthin, plus derivatives of these carotenoids that have been recently identified (Garrido \& Zapata 1998). The concentrations of these pigments vary among different species or even among strains of the same species (Buma et al. 1991, Stolte et al. 2000) as well as in a given species according to the light and nutrient conditions to which the cells are exposed (Van Leeuwe \& Stefels 1998, Stolte et al. 2000). It has been found that the amount of 19'-hexanoyloxyfucoxanthin increased with an increase in light intensity, leading Van Leeuwe \& Stefels (1998) to suggest that 19'-hexanoyloxyfucoxanthin might be less efficient in transferring energy to chl a. Nevertheless, there is still no concrete evidence for this hypothesis. In fact, at least 2 research groups (Haxo 1985, Johnsen et al. 1992, Johnsen \& Sakshaug 1993) have shown a light-harvesting function for 19'hexanoyloxyfucoxanthin. Recently, Stolte et al. (2000) have proposed that the pathway of synthesis of carotenoids in Emiliania huxleyi (a haptophyte) has steps leading from diadinoxanthin to fucoxanthin and from fucoxanthin to 19'-hexanoyloxyfucoxanthin. They suggested that the last of these conversions might be promoted by high irradiance. Our results show that, on an ocean-basis average, there was no significant difference in the ratio of $19^{\prime}$-hexanoyloxyfucoxanthin to chl $a$ at the surface, where irradiance was high, from that at the DCM, where irradiance was low. This differs from the pattern shown by fucoxanthin, the other main PS carotenoid, which was significantly more abundant at the DCM than at the surface. A similar pattern, with higher levels of 19'-hexanoyloxyfucoxanthin than fucoxanthin at high light, has been found in cultures of the haptophyte Emiliania huxleyi grown under different irradiances (E. Head unpubl.). Johnsen et al. (1997) found that dinoflagellates increase the number of light-harvesting complexes containing the usual PS carotenoid, peridinin, as well as the PP carotenoid, diadinoxanthin, when they are exposed to high light. Thus, we can speculate that in haptophytes an increase in irradiance could produce an increase in the amount of pigment-protein complexes containing both PP pigments and 19'-hexanoyloxyfucoxanthin. More work will be necessary to explain the regulation of the synthesis of fucoxanthin and 19'-hexanoyloxyfucoxanthin in haptophytes, as well as the configuration of these pigments into different pigment-protein com- 
plexes and their efficiency of energy transfer. This may help to understand the wide distribution of haptophytes in the ocean (Jeffrey \& Anderson 2000).

The general trends found in the ratios of PS and PP carotenoids to chl a (Fig. 5) and in the phycoerythrin fluorescence per Synechococcus cell (Fig. 6), are indicative of changes in species composition or photoacclimation within a species, or both. The fact that changes were observable with depth, however, implies that the rate of mixing in the upper water column was low enough to allow stratification either in the distribution of different species (e.g. Moore et al. 1995) or in acclimation of the cells to different irradiances (e.g. Falkowski 1983, Cullen et al. 1988), or both. Changes in pigment ratios with depth can also be caused by changes in species composition or physiological state of the cells due to the increased availability of nutrients with depth (e.g. Margalef 1978, Yentsch \& Phinney 1989, Chisholm 1992).

\section{Effect of group composition and photoacclimation on the optical characteristics of phytoplankton}

\section{Variability in the absorption spectra}

The lower variation found in the values of chl $a$ and $a_{p h}(440)$ for the small fraction compared with the large fraction or the total (Table 3) supports the idea that there is a background of phytoplankton biomass produced by small cells in the ocean, which is augmented by large cells in coastal or nutrient-rich areas (Chisholm 1992, Malone 1980, Yentsch \& Spinrad 1987, Yentsch 1990). On the other hand, our data do not suggest uniformity in species composition within the small fraction. For example, when absorption spectra were normalized at $623 \mathrm{~nm}$ (Fig. 10), coefficients of variation at other wavelengths were higher for the small than for the large fraction. At most of the stations, the percentage contribution of picophytoplankton to $a_{p h}(440)$ was greater than their contribution to total chl $a$, which is consistent with the fact that small cells have a higher absorption efficiency (i.e. lower packaging effect) than large cells. The same effect was apparent in the comparison of the normalized (at $623 \mathrm{~nm}$ ) absorption spectra for the different fractions, which showed higher values of absorption at the blue and red peaks for the small fraction than for the large fraction or for the total (Fig. 10).

A clear indication of the important contribution of PP pigments (or non-PS pigments) to the absorption spectrum of phytoplankton was found in this study. The values of $a_{p h}(440) / a_{p h}(676)$ obtained in these samples from the Labrador and North Central Atlantic had a slightly lower range (1.5 to 3.2 ) than the range (2 to 4.5 ) found by Sosik \& Mitchell (1995) in the California Current System. This ratio was correlated with the ratio of PP pigments to chl a (Fig. 7). The correlation between $a_{p h}(440) / a_{p h}(676)$ and the ratio of zeaxanthin to chl a was also high, suggesting that zeaxanthin might have been responsible for much of the variation in absorption by PP pigments (Fig. 7). This contribution of zeaxanthin to absorption in the blue peak is well known from laboratory experiments with Prochlorococcus (e.g. Moore et al. 1995) and with Synechococcus (e.g. Bidigare et al. 1989), and also from field studies in the Equatorial Pacific (Alalli et al. 1997). Zeaxanthin is often associated with small cells, mainly picoprokaryotes (e.g. Synechococcus and Prochlorococcus), which contain high concentrations of this pigment and small chlorophytes (picoeukaryotes). Hence, both the small cell size (low packaging effect) and the enhanced absorption in the blue by zeaxanthin favor high values of $a_{p h}(440) / a_{p h}(676)$. There was no discernable correlation between $a_{p h}(440) / a_{p h}(676)$ and the ratio of diadinoxanthin+diatoxantin to $\mathrm{chl}$ a. These xanthophylls, having an important PP function (Demmig-Adams 1990, Demers et al. 1991, Olaizola \& Yamamoto 1994), are found in low intracellular concentrations in diatoms and dinoflagellates, and hence they have a lower effect on the shape of the absorption spectrum than that of zeaxanthin which is found in larger concentrations in small size cells like Synechococcus and Prochlorococcus. The ratio of PS carotenoid to chl a had a negative correlation with the ratio $a_{p h}(440) / a_{p h}(676)$ as expected: the concentration of PS carotenoids increases with depth as a result of photoacclimation to low irradiances. The ratio of fucoxanthin to chl a showed a high negative correlation to $a_{p h}(440) /$ $a_{p h}(676)$. On the other hand, the ratio of $19^{\prime}$-hexanoyloxyfucoxanthin to chl a had a much lower positive correlation with $a_{p h}(440) / a_{p h}(676)$. Fucoxanthin is the main PS carotenoid in diatoms and is also present in haptophytes and some species of dinoflagellates, which are usually of large cell size (except for haptophytes). Additionally, its concentration increases with a decrease in irradiance. Both the large size and the high intracellular concentration tend to increase the packaging effect and lead to a low ratio $a_{p h}(440) /$ $a_{p h}(676)$. The pigment 19 '-hexanoyloxyfucoxanthin is present in haptophytes, which are usually of small cell size, and its concentration seems to increase with irradiance, and therefore it is associated with a decrease in the chl a concentration and a lower packaging effect.

We found that the percentage contribution of PP pigment absorption at the blue ( $\left.\% a_{P P}(440)\right)$ was considerably higher at the surface than at the DCM. Thus, high ratios of $a_{p h}(440) / a_{p h}(676)$ in the ocean might be due to absorption by PP pigments not contributing to photosynthesis. This will in turn influence the estimation of 
primary production by spectral models (Sathyendranath et al. 1989, Kyewalyanga et al. 1992), and could also affect the estimation of chl a by remote sensing (based on an empirical relationship between chl a concentration and the ratio of reflectance in the blue and green regions of the spectrum). Morel (1997) showed that during a bloom of Synechococcus, chl a concentration calculated from reflectance values would have been overestimated by a factor of 3 if the usual algorithms for Case 1 waters were used.

Morel (1997) showed that the presence of Synechococcus could be detected by a characteristic lowering in the reflectance spectrum at around $548 \mathrm{~nm}$ caused by phycoerythrin absorption. He estimated that the magnitude of this feature would be too low to allow a quantitative estimation of the biomass of Synechococcus, but that it would provide a flag for the presence of these algae. In such cases, estimation of chl a by remote sensing should be done applying algorithms appropriate for cyanobacteria, to avoid the overestimation caused by common algorithms for Case 1 waters (Morel 1997). The work presented here suggests that another way of detecting the presence of Synechococcus could be through the relationship between the ratio $a_{p h}(555) / a_{p h}(623)$ and the relative number of Synechococcus in the samples (Fig. 8). This ratio is examined here because previous experiments with unialgal cultures (unpubl. data) showed a distinct change in the ratio with species: the mean $a_{p h}(555) /$ $a_{p h}(623)$ ratio in diatoms was $\sim 1.00 \pm 0.12$ (for 7 samples of Thalassiosira weissflogii and Chaetoceros sp.), whereas it was $\sim 5.45 \pm 0.77$ in cyanobacteria (for 3 samples of Synechococcus sp.). Several factors, involving changes in the type of phycobilin they contain and photoacclimation of the cells (Glover et al. 1985, Wood 1985, Li \& Wood 1988, Wood et al. 1999), can, however, confound the relationship of $a_{p h}(555) / a_{p h}(623)$ versus relative number of cyanobacteria in natural samples. It should be also noted that at $623 \mathrm{~nm}$, there is only a minor peak of absorption by chl a (and also chl $C$ ), so that this region of the spectrum is probably more affected by errors in estimating the absorption values. Despite these possible limitations, this relationship could be useful as an alternative way of identifying the presence of cyanobacteria from the simple measurement of the absorption spectrum in situ, or in the future, through the use of hyperspectral remotesensors able to estimate reflectance at those wavebands (IOCCG 1998).

\section{Variability in fluorescence excitation spectra}

Significant variations were found in the fluorescence excitation spectrum, $f_{C}(\lambda)$, in the different cell sizes
(>2 $\mu \mathrm{m}$ and $<2 \mu \mathrm{m})$. These variations support the idea that the shape of the fluorescence excitation spectrum is far from being conservative and that it changes with cell size and species composition (Goedheer 1969, Larkum \& Barrett 1983, Neori et al. 1988, Kiefer \& Reynolds 1992, Govindjee 1995, Lutz et al. 1998). The small size fraction of phytoplankton showed a larger variation in $f_{C}(440)$ than the large size fraction (Table 3). This might have been due to variations in the distribution of phycoerythrin-containing cyanobacteria, as the spectral shapes of the fluorescence excitation spectra showed a maximum CV at $\sim 550 \mathrm{~nm}$ (Fig. 10). It is known that the fluorescence excitation spectrum of phytoplankton depends on the organization of pigments within the PS membranes (e.g. Larkum \& Barrett 1983, Neori et al. 1988). Fluorescence emission at ambient temperature originates mainly (>95\%) from Photosystem II (PSII; Goedheer 1969, Kiefer \& Reynolds 1992, Govindjee 1995). Thus, cyanobacteria showing an extreme case of imbalance in chl a distribution between photosystems, have a fluorescence excitation spectra with a strong peak at the maximum of absorption by phycobilins (associated with PSII), and low fluorescence at the maxima of absorption by chl a (mostly located in PSI; Ley \& Butler 1980). This would explain why the contribution of the small fraction to total $f_{C}(440)$ was lower than its contribution to total $a_{p h}(440)$ at stations where the phytoplankton was dominated by cyanobacteria (Fig. 9). Other factors which also can influence the variability in $f_{C}(550)$ in the small fraction are: the filter correction in the fluorescence excitation spectra (ratio between fluorescence in suspension and on a filter; Lutz et al. 1998), possible effects of stress on the cells which were pre-filtered through a Nuclepore filter, and a probable low signal-to-noise ratio. At stations where the picophytoplankton were comprised mainly of Prochlorococcus, haptophytes and (probably) chlorophytes, the contribution of the small fraction to total $f_{c}(440)$ was larger than its contribution to total $a_{p h}(440)$. In this case, one possible explanation for the low contribution to $f_{C}(440)$ by the large fraction might have been the presence of haptophytes containing 19-hexanoyloxyfucoxanthin, which might be associated with a specific arrangement of the pigment-protein complexes, resulting in a lower efficiency of energy transfer to PSII. These results prove once more that variations in the shape of the fluorescence excitation spectrum should be taken into account when this spectrum is used to represent the action spectrum in models to estimate primary production (Sakshaug et al. 1991, Babin et al. 1995, Sosik \& Mitchell 1995). Variations in species composition, with different arrangements of the PS apparatus, might also affect passive fluorescence emission. This factor should be considered when attempting to estimate chl a concentration by remote sensing of fluorescence. 


\section{CONCLUDING REMARKS}

The observations reported here confirm that there is a substantial variability in phytoplankton distribution in these regions of the North Atlantic. The distribution of the phytoplankton communities was marked by differences in photoadaptation (i.e. different suites of pigments occurred in different taxonomical classes). Photoacclimation of cells to different intensities of irradiance, with depth, was also notable. Changes in pigment composition and cell size had a significant influence on the in vivo absorption and fluorescence excitation spectra of phytoplankton. Some significant relationships between the shape of the absorption spectrum and some indices of phytoplankton composition (e.g. between $a_{p h}(440) / a_{p h}(676)$ and zeaxanthin/ chl $a_{i}$ and between $a_{p h}(555) / a_{p h}(623)$ and Synechococcus cells/chl a) were found.

At the large scale, that is, considering average values from all stations in the Labrador Sea and the Central North Atlantic, large cells $(>2 \mu \mathrm{m})$ dominated the biomass (chl $a$ concentration) and the magnitude of the optical properties $\left(a_{p h}[440], f_{c}[440]\right)$ of the phytoplankton. At a local scale, considering individual stations, there were significant differences in the dominance of the large and small $(<2 \mu \mathrm{m})$ size fractions of phytoplankton. For example, in the clear open ocean stations, the small size fraction contributed between 40 and $100 \%$ of the total chl $\mathrm{a}$ and of the total values of $a_{p h}(440)$ and $f_{c}(440)$. Variations in the shape of the absorption and fluorescence excitation spectra were similar for both the small and large size fractions of the phytoplankton.

These results emphasize the importance of accounting for spectral variations in the absorption and fluorescence excitation spectra in models to estimate primary production, especially at local scales. The relationships found between the shape of the absorption spectrum and species or pigment composition might be useful to characterize some phytoplankton communities in the ocean from easily measured optical properties.

\section{LITERATURE CITED}

Allali K, Bricaud A, Claustre H (1997) Spatial variations in the chlorophyll-specific absorption coefficients of phytoplankton and photosynthetically active pigments in the equatorial Pacific. J Geophys Res 102:12413-12423

Babin M, Therriault JC, Legendre L, Niecke B, Reuter R, Condal A (1995) Relationship between the maximum quantum yield of carbon fixation and the minimum quantum yield of chlorophyll a in vivo fluorescence in the Gulf of St. Lawrence. Limnol Oceanogr 40:956-968

Babin M, Morel A, Claustre H, Bricaud A, Kolber Z, Falkowski PG (1996) Nitrogen- and irradiance-dependent variations of the maximum quantum yield of carbon fixa- tion in eutrophic, mesotrophic and oligotrophic marine systems. Deep-Sea Res I 43:1241-1272

Bidigare RR, Schofield O, Prézelin BB (1989) Influence of zeaxanthin on quantum yield of photosynthesis of Synechococcus clone WH7803 (DC2). Mar Ecol Prog Ser 56:177-188

Bidigare RR, Marra J, Dickey TD, Iturriaga R, Baker KS, Smith RC, Pak H (1990a) Evidence for phytoplankton succession and chromatic adaptation in the Sargasso Sea during spring 1985. Mar Ecol Prog Ser 60:113-122

Bidigare RR, Ondrusek ME, Morrow JH, Kiefer DA (1990b) In vivo absorption properties of algal pigments. SPIE Vol 1302, Ocean Optics X 1302:290-302

Boczar B, Prézelin BB (1989) Organization and comparison of chlorophyll-protein complexes from two fucoxanthincontaining algae: Nitzchia closterium (Bacillariophyceae) and Isochrysis galbana (Prymnesiophyceae). Plant Cell Physiol 30:1047-1056

Bonaventura C, Myers J (1969) Fluorescence and oxygen evolution from Chlorella pyreneidosa. Biochim Biophys Acta 189:366-383

Buma AGJ, Bano N, Veldhuis MJW, Kraay GW (1991) Comparison of the pigmentation of two strains of the prymnesiophyte Phaeocystis sp. Neth J Sea Res 27:173-182

Chisholm SW (1992) Phytoplankton size. In: Falkowski PG, Woodhead $\mathrm{AD}$ (eds) Primary productivity and biogeochemical cycles in the sea. Plenum Press, New York, p 213-237

Chisholm SW, Olson RJ, Zettler ER, Waterbury J, Goericke R, Welschmeyer N (1988) A novel free-living prochorophyte occurs at high cell concentrations in the oceanic euphotic zone. Nature 334:340-343

Cullen JJ, Lewis MR (1988) The kinetics of algal photoadaptation in the context of vertical mixing. J Plankton Res 10: 1039-1063

Culver ME, Davis RF, Perry MJ (1994) Instrumental considerations for deriving spectral photosynthetic absorption coefficients from total phytoplankton absorption. In: Jaffe JS (ed) Ocean Optics XII Proc SPIE 2258:123-133

Demers S, Roy S, Gagnon R, Vignault C (1991) Rapid lightinduced changes in cell fluorescence and in xanthophyllcycle pigments of Alexandrium excavatum (Dinophyceae) and Thalassiosira pseudonana (Bacillariophyceae): a photoprotection mechanism. Mar Ecol Prog Ser 76:185-193

Demmig-Adams B (1990) Carotenoids and photoprotection in plants: a role for the xanthophyll zeaxanthin. Biochim Biophys Acta 1020:1-24

Duysens LNM (1956) The flattening of the absorption spectrum of suspensions, as compared to that of solutions. Biochim Biophys Acta 19:1-12

Edvardsen B, Eikrem W, Green JC, Andersen RA, MoonVan der Staay SY (2000) Phylogenetic reconstructions of Haptophyta inferred from $18 \mathrm{~S}$ ribosomal DNA sequences and available morphological data. Phycologia 39:19-35

Falkowski PG (1983) Light-shade adaptation and vertical mixing of marine phytoplankton: a comparative field study. J Mar Res 41:215-237

Falkowski PG, La Roche J (1991) Acclimation to spectral irradiance in algae. $\mathrm{J}$ Phycol 27:8-14

Garrido JL, Zapata M (1998) Detection of new pigments from Emiliania huxleyi (Prymnesiophycea) by highperformance liquid chromatography, liquid chromatography-mass spectrometry, visible spectroscopy and fast atom bombardment mass spectrometry. J Phycol 34:70-78

Gieskes WCW, Kraay GW, Nontji A, Setiapermana D, Sutomo (1988) Monsoonal alternation of a mixed and a layered structure in the phytoplankton of the euphotic zone of the 
Banda Sea (Indonesia): a mathematical analysis of algal pigment fingerprints. Neth J Sea Res 22:123-137

Glover HE, Phinney DA, Yentsch CS (1985) Photosynthetic characteristics of picophytoplankton compared with those of larger phytoplankton populations, in various water masses in the Gulf of Maine. Biol Oceanogr 3:223-248

Glover HE, Keller MD, Guillard RRL (1986) Light quality and ultraphytoplankters. Nature 319:142-143

Goedheer JC (1969) Energy transfer from carotenoids to chlorophyll in blue-green algae and greening bean leaves. Biochim Biophys Acta 172:252-265

Gordon HR, Morel A (1983) Remote assessment of ocean color for interpretation of satellite visible imagery. A review. In: Barber RT, Mooers NK, Bowman MJ, Zeitzschel B (eds) Lecture notes on coastal and estuarine studies, Vol 4. Springer Verlag, New York, p 114

Govindjee (1995) Sixty-three years since Kautsky: chlorophyll a fluorescence. Aust J Plant Physiol 22:131-160

Haxo FT (1985) Photosynthetic action spectrum of the coccolithophorid, Emiliania huxleyi (Haptophyceae): 19'-hexanoyloxyfucoxanthin as antenna pigment. J Phycol 21:282-287

Head EJH, Horne EPW (1993) Pigment transformation and vertical flux in an area of convergence in the North Atlantic. Deep-Sea Res II 40:329-346

Head EJH, Harris LR, Campbell RW (2000) Investigations on the ecology of Calanus spp. in the Labrador Sea. I. Relationship between the phytoplankton bloom and reproduction and development of Calanus finmarchicus in spring. Mar Ecol Prog Ser 193:53-73

Hoepffner N, Sathyendranath S (1991) Effect of pigment composition on absorption properties of phytoplankton. Mar Ecol Prog Ser 73:11-23

Hoepffner N, Sathyendranath S (1992) Bio-optical characteristics of coastal waters: absorption spectra of phytoplankton and pigment distribution in the western North Atlantic. Limnol Oceanogr 8:1660-1679

Hoepffner N, Sathyendranath S (1993) Determination of the major groups of phytoplankton pigments from the absorption spectra of total particulate matter. J Geophys Res 98:22789-22803

Hulburt ED (1983) The unpredictability of the marine phytoplankton. Ecology 64:1157-1170

Hutchinson GE (1961) The paradox of the plankton. Am Nat 95:137-145

IOCCG (1998) Minimum requirements for an operational ocean-colour sensor for the open ocean. In: Morel A (ed) Reports of the International Ocean-Colour Coordinating Group, No. 1, IOCCG, Dartmouth, p 46

Jeffrey SW, Anderson JM (2000) Emiliania huxleyi (Haptophyta) holds promising insights for photosynthesis. J Phycol 36:449-452

Jeffrey SW, Vesk M (1997) Introduction to marine phytoplankton and their pigment signatures. In: Jeffrey SW, Mantoura RFC, Wright SW (eds) Phytoplankton pigments in oceanography: guidelines to modern methods. SCORUNESCO, Paris, p 37-84

Jeffrey SW, Mantoura RFC, Bjørland T (1997) Data for the identification of 47 key phytoplankton pigments. In: Jeffrey SW, Mantoura RFC, Wright SW (eds) Phytoplankton pigments in oceanography: guidelines to modern methods. SCOR-UNESCO, Paris, p 449-559

Johnsen G, Sakshaug E (1993) Bio-optical characteristics and photoadaptive responses in the toxic and bloom-forming dinoflagellates Gyrodinium aureolum, Gymnodinium galatheanum, and two strains of Prorocentrum minimum. J Phycol 29:627-642

Johnsen G, Sakshaug E, Vernet M (1992) Pigment composi- tion, spectral characterization and photosynthetic parameters in Chrysochromulina polylepis. Mar Ecol Prog Ser 83:241-249

Johnsen G, Samset O, Granskog L, Sakshaug E (1994) In vivo absorption characteristics in 10 classes of bloom-forming phytoplankton: taxonomic characteristics and responses to photoadaptation by means of discriminant and HPLC analysis. Mar Ecol Prog Ser 105:149-157

Johnsen G, Prézelin BB, Jovine RVM (1997) Fluorescence excitation spectra and light utilization in two red tide dinoflagellates. Limnol Oceanogr 42:1166-1177

Johnson PW, Sieburth J McN (1979) Chroococcoid cyanobacteria in the sea: a ubiquitous and diverse phototrophic biomass. Limnol Oceanogr 24:928-935

Kana TM, Glibert PM, Goericke R, Welschmeyer NA (1988) Zeaxanthin and $\beta$-carotene in Synechococcus WH7803 respond differently to irradiance. Limnol Oceanogr 33: 1623-1627

Kiefer DA, Reynolds RA (1992) Advances in understanding phytoplankton fluorescence and photosynthesis. In: Falkowski PG, Woodhead AD (eds.) Primary productivity and biogeochemical cycles in the sea. Plenum Press, New York, p 155-174

Kiørboe T (1993) Turbulence, phytoplankton cell size, and the structure of pelagic food webs. Adv Mar Biol 29:1-72

Kirk JTO (1994) Light and photosynthesis in aquatic ecosystems, 2nd edn. Cambridge University Press, Cambridge, p 509

Kishino M, Takahashi M, Okami N, Ichimura S (1985) Estimation of the spectral absorption coefficients of phytoplankton in the sea. Bull Mar Sci 37:634-642

Kyewalyanga MN, Platt T, Sathyendranath S (1992) Ocean primary production calculated by spectral and broad-band models. Mar Ecol Prog Ser 85:171-185

Kyewalyanga MN, Platt T, Sathyendranath S (1997) Estimation of the photosynthetic action spectrum: implication for primary production models. Mar Ecol Prog Ser 146: $207-223$

Kyewalyanga MN, Platt T, Sathyendranath S, Lutz VA, Stuart V (1998) Seasonal variations in physiological parameters of phytoplankton across the North Atlantic. J Plankton Res 20:17-42

Larkum AWD, Barrett J (1983) Light-harvesting processes in algae. Adv Bot Res 10:1-219

Lazier JRN, Wright DG (1993) Annual velocity variations in the Labrador Current. J Phys Oceanogr 23:659-678

Ley AC, Butler WL (1980) Effects of chromatic adaptation on the photochemical apparatus of photosynthesis in Porphyridium cruentum. Plant Physiol 65:714-722

Li WKW (1994) Phytoplankton biomass and chlorophyll concentrations across the North Atlantic. Sci Mar 58:67-79

Li WKW (1995) Composition of ultraplankton in the Central North Atlantic. Mar Ecol Prog Ser 122:1-8

Li WKW (1998) Annual average abundance of heterotrophic bacteria and Synechococcus in surface ocean waters. Limnol Oceanogr 43:1746-1753

Li WKW, Wood M (1988) Vertical distribution of North Atlantic ultraphytoplankton: analysis by flow cytometry and epifluorescence microscopy. Deep-Sea Res 35:1615-1638

Longhurst A (1998) Ecological geography of the sea. Academic Press, San Diego, CA, p 398

Lutz VA, Sathyendranath S, Head EJH, Li WKW (1998) Differences between in vivo absorption and fluorescence excitation spectra in natural samples of phytoplankton. J Phycol 34:214-227

Lutz VA, Sathyendranath S, Head EJH, Li WKW (2001) Changes in the in vivo absorption and fluorescence exci- 
tation spectra with growth irradiance in three species of phytoplankton. J Plankton Res 23:555-569

Mackey MD, Mackey DJ, Higgins HW, Wright SW (1996) CHEMTAX - a program for estimating class abundances from chemical markers: application to HPLC measurements of phytoplankton. Mar Ecol Prog Ser 144:265-283

Malone TC (1980) Algal size. In: Morris I (ed) The physiological ecology of phytoplankton. Studies in ecology, Vol 7. University of California Press, Berkeley and Los Angeles, p 433-463

Margalef R (1978) Life-forms of phytoplankton as survival alternatives in an unstable environment. Oceanol Acta 1: 493-510

Mitchell BG (1990) Algorithms for determining the absorption coefficient for aquatic particulates using the quantitative filter technique. Ocean Optics 10, Proc SPIE 1302:137-148

Moore L, Goericke R, ChisholmSW (1995) Comparative physiology of Synechococcus and Prochlorococcus: influence of light and temperature on growth, pigments, fluorescence and absorptive properties. Mar Ecol Prog Ser 116: $259-275$

Morel A (1978) Available, usable, and stored radiant energy in relation to marine photosynthesis. Deep-Sea Res 25: 673-688

Morel A (1997) Consequences of a Synechococcus bloom upon the optical properties of oceanic (case 1) waters. Limnol Oceanogr 42:1746-1754

Morel A, Bricaud A (1981) Theoretical results concerning light absorption in a discrete medium, and application to specific absorption of phytoplankton. Deep-Sea Res 28: 1375-1393

Neori A, Vernet M, Holm-Hansen O, Haxo FT (1988) Comparison of chlorophyll far-red and red fluorescence excitation spectra with photosynthetic oxygen action spectra for photosystem II in algae. Mar Ecol Prog Ser 44:297-302

Olaizola M, Yamamoto HY (1994) Short-term response of the diadinoxanthin cycle and fluorescence yield to high irradiance in Chaetoceros muelleri (Bacillariophyceae). J Phycol 30:606-612

Olaizola M, Geider RJ, Harrison WG, Graziano LM, Ferrari GM, Schlittenhardt PM (1996) Synoptic study of variations in the fluorescence-based maximum quantum efficiency of photosynthesis across the North Atlantic Ocean. Limnol Oceanogr 41:755-765

Platt T, Li WKW (eds) (1986) Photosynthetic picophytoplankton. Can Bull Fish Aquat Sci 214:1-583

Porra RJ, Pfündel EE, Engel N (1997) Metabolism and function of photosynthetic pigments. In: Jeffrey SW, Mantoura RFC, Wright SW (eds) Phytoplankton pigments in oceanography: guidelines to modern methods. SCOR-UNESCO, Paris, p 85-126

Prézelin BB (1981) Light reactions in photosynthesis. In: Platt T (ed) Physiological bases of phytoplankton ecology. Can Bul Fish Aquat Sci 210:1-43

Reynauld TH, Weaver AJ, Greatbatch RJ (1995) Summer mean circulation of the northwestern Atlantic Ocean. J Geophys Res 100:779-816

Richardson K, Beardall J, Raven JA (1983) Adaptation of unicellular algae to irradiance: an analysis of strategies. New Phytol 93:157-191

Rowan KS (1989) Photosynthetic pigments of algae. Cambridge University Press, Cambridge

Sakshaug E, Johnsen G, Andersen K, Vernet M (1991) Modeling of light-dependent algal photosynthesis and growth: experiments with the Barents Sea diatoms Thalassiosira nordenskioeldii and Chaetoceros furcellatus. Deep-Sea Res 38:415-430
Sathyendranath S, Platt T (1988) The spectral irradiance field at the surface and in the interior of the ocean: a model for applications in oceanography and remote sensing. J Geophys Res 93:9270-9280

Sathyendranath S, Platt T (1989) Remote sensing of ocean chlorophyll: consequence of non-uniform pigment profile. Appl Optics 28:490-495

Sathyendranath S, Lazzara L, Prieur L (1987) Variations in the spectral values of specific absorption of phytoplankton. Limnol Oceanogr 32:403-415

Sathyendranath S, Platt T, Caverhill CM, Warnock RE, Lewis MR (1989) Remote sensing of oceanic primary production: computations using a spectral model. Deep-Sea Res 36: 431-453

Smetacek V (1998) How mainstream biological oceanography can profit from harmful-algal-bloom studies and vice versa. In: Reguera B, Blanco J, Fernández ML, Wyatt T (eds) Harmful algae. Xunta de Galicia and IOC of UNESCO, Paris, p 109-113

Siefermann-Harms D (1987) The light-harvesting and protective functions of carotenoids in photosynthetic membranes. Physiol Plant 69:561-568

Sosik HM, Mitchell BG (1995) Light absorption by phytoplankton, photosynthetic pigments and detritus in the California Current System. Deep-Sea Res I 42:1717-1748

Stolte W, Kraay GW, Noordeloos AAM, Riegman R (2000) Genetic and physiological variation in pigment composition of Emiliania huxleyi (Prymnesiophyceae) and the potential use of its pigment ratios as a quantitative physiological marker. J Phycol 36:449-452

Stuart V, Sathyendranath S, Platt T, Maass H, Irwin BD (1998) Pigments and species composition of natural populations: effect on the absorption spectra. J Plankton Res 20:187-217

Stuart V, Sathyendranath S, Head EJH, Platt T, Irwin BD, Maass H (2000) Bio-optical characteristics of diatom and prymnesiophyte populations in the Labrador Sea. Mar Ecol Prog Ser 201:91-106

Takahashi M, Ichimura I, Kishino M, Okami N (1989) Shade and chromatic adaptation of phytoplankton photosynthesis in a thermally stratified sea. Mar Biol 100:401-409

Van Leeuwe MA, Stefels J (1998) Effects of iron and light stress on the biochemical composition of antarctic Phaeocystis sp. (prymnesiophyceae). II. Pigment composition. J Phycol 34:496-503

Veldhuis MJW, Kraay GW (1990) Vertical distribution and pigment composition of a picophytoplanktonic prochlorophyte in the subtropical North Atlantic: a combined study of HPLC-analysis of pigments and flow cytometry. Mar Ecol Prog Ser 68:121-127

Vernet M, Mitchell BG, Holm-Hansen O (1990) Adaptation of Synechococcus in situ determined by variability in intracellular phycoerythrin-543 at a coastal station off Southern California coast, USA. Mar Ecol Prog Ser 63:9-16

Waser NAD, Harrison WG, Head EJH, Lutz VA, Calvert SE, Nielsen B (2000) Geographic variations in ${ }^{15} \mathrm{~N}$ natural abundance of surface particulate nitrogen and new production across the North Atlantic ocean. Deep-Sea Res I 47:1207-1226

Wood AM (1985) Adaptation of photosynthetic apparatus of marine ultraphytoplankton to natural light fields. Nature 316:253-255

Wood AM, Phinney DA, Yentsch CS (1998) Water column transparency and the distribution of spectrally distinct forms of phycoerythrin-containing organisms. Mar Ecol Prog Ser 162:25-31

Wood AM, Lipsen M, Coble P (1999) Fluorescence-based characterization of phycoerythrin-containing cyanobacte- 
rial communities in the Arabian Sea during the Northeast and early Southwest Monsoon (1994-1995). Deep-Sea Res II 46:1769-1790

Wyman M (1992) An in vivo method for the estimation of phycoerythrin concentrations in marine cyanobacteria Synechococcus spp. Limnol Oceanogr 37:1300-1306

Yentsch CS (1962) Measurement of visible light absorption by particulate matter in the ocean. Limnol Oceanogr 7: 207-217

Editorial responsibility: Otto Kinne (Editor),

Oldendorf/Luhe, Germany
Yentsch CM (1990) Environmental health: Flow cytometric methods to assess our water world. Meth Cell Biol 33: $575-612$

Yentsch CS, Phinney DA (1989) A bridge between ocean optics and microbial ecology. Limnol Oceanogr 34: 1694-1705

Yentsch CM, Spinrad RW (1987) Particles in flow. Mar Technol Soc J 21:58-68

Submitted: February 17, 2000; Accepted: June 24, 2003

Proofs received from author(s): September 8, 2003 